
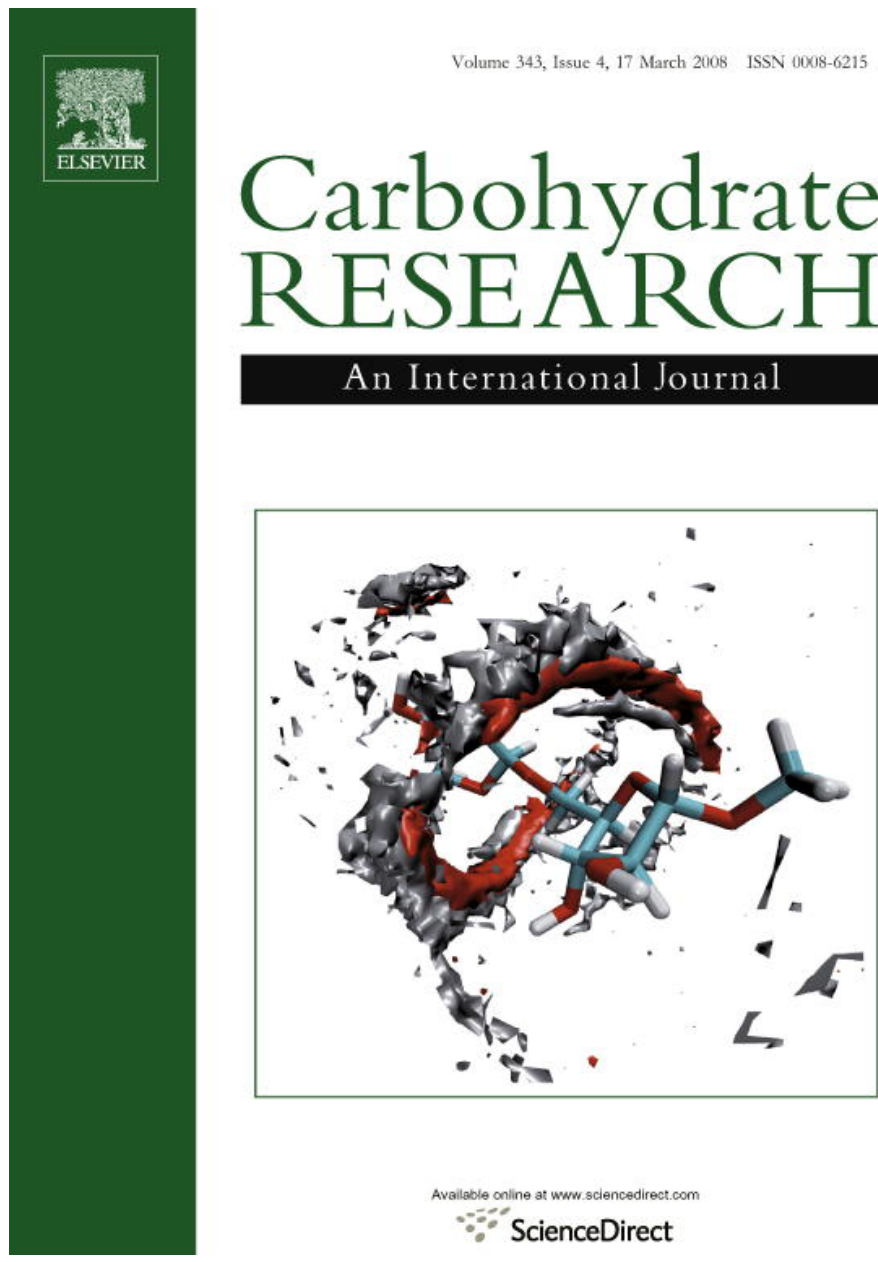

$\because$ ScienceDirect

This article was published in an Elsevier journal. The attached copy

is furnished to the author for non-commercial research and education use, including for instruction at the author's institution, sharing with colleagues and providing to institution administration.

Other uses, including reproduction and distribution, or selling or licensing copies, or posting to personal, institutional or third party websites are prohibited.

In most cases authors are permitted to post their version of the article (e.g. in Word or Tex form) to their personal website or institutional repository. Authors requiring further information regarding Elsevier's archiving and manuscript policies are encouraged to visit: 


\title{
Structural studies on exopolysaccharides produced by three different propionibacteria strains
}

\author{
Justyna M. Dobruchowska, ${ }^{\mathrm{a}, \mathrm{b}}$ Gerrit J. Gerwig, ${ }^{\mathrm{a}}$ Andrzej Babuchowski ${ }^{\mathrm{b}}$ and \\ Johannis P. Kamerling ${ }^{\mathrm{a}, *}$ \\ ${ }^{a}$ Bijvoet Center, Department of Bio-Organic Chemistry, Utrecht University, Padualaan 8, 3584 CH Utrecht, The Netherlands \\ ${ }^{\mathrm{b}}$ Chair of Food Biotechnology, University of Warmia and Mazury, Heweliusza 1, 10-957 Olsztyn, Poland \\ Received 16 November 2007; accepted 10 December 2007 \\ Available online 8 January 2008
}

\begin{abstract}
The exopolysaccharides produced by three propionibacteria strains, Propionibacterium freudenreichii 109, Propionibacterium freudenreichii 111, and Propionibacterium thoenii 126, grown on whey-based media, were found to be charged heteropolymers, composed of D-glucose, D-mannose, and D-glucuronic acid in molar ratios of 2:2:1. By means of methylation analysis, mass spectrometry, partial acid hydrolysis, and 1D/2D NMR $\left({ }^{1} \mathrm{H}\right.$ and $\left.{ }^{13} \mathrm{C}\right)$ studies, it was determined that all three exopolysaccharides contain the same branched, pentasaccharide repeating unit:
\end{abstract}

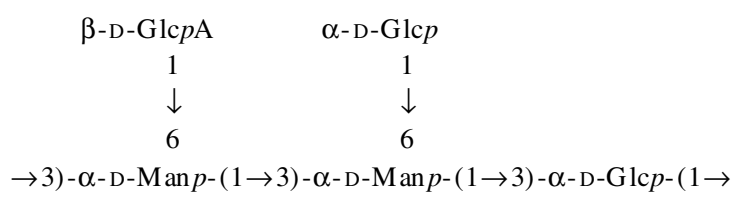

(C) 2007 Elsevier Ltd. All rights reserved.

Keywords: Propionibacterium; Exopolysaccharide; EPS; Structural analysis; NMR; MS

\section{Introduction}

In the food industry, microbial exopolysaccharides (EPSs) are widely used as viscosifying, stabilizing, emulsifying, gelling, and water-binding agents. ${ }^{1,2}$ The foodgrade bacteria known for their ability to produce EPS are mostly lactic acid bacteria, ${ }^{3,4}$ but also bifidobacteria and propionibacteria. ${ }^{5}$

Propionibacteria, a heterogeneous group of anaerobic or microaerophilic Gram-positive microorganisms, are traditionally applied as dairy starters for Swiss-type cheeses. Furthermore, they are used for the commercial production of propionic acid, bacteriocins, and B-vitamins. ${ }^{6,7}$ The dairy propionibacteria, for example, Pro-

\footnotetext{
* Corresponding author. Tel.: +31 30 2533479; fax: +31 30 2540980; e-mail: j.p.kamerling@uu.nl
}

pionibacterium freudenreichii ssp. shermanii, have been considered as potential probiotic organisms. ${ }^{8}$

Exopolysaccharides produced by propionibacteria have been much less investigated than those from lactic acid bacteria. ${ }^{9,10}$ So far, research has mainly been focused on growth conditions and production kinetics, but little is known about the carbohydrate structure of EPSs produced by propionibacteria species. The most frequently identified monosaccharides in polysaccharides formed by these bacteria are glucose, galactose, mannose, and small amounts of glucosamine, galactosamine, fucose, and rhamnose. ${ }^{11-13}$ Only one structural study of an EPS from a propionibacterium, $P$. freudenreichii ssp. shermanii $\mathrm{JS}$, has been reported. ${ }^{14}$ Investigation of the structures of the EPSs from propionibacteria is important to get more insight into their physical behavior, and for the understanding of the role of EPS in many different processes, such as 
immune defense, parasitic infections, and inflammation. ${ }^{15,16}$ Knowledge of the structures of EPSs will also support studies aimed at unraveling the metabolic pathways by which they are synthesized.

Here, we present the structure of the EPS produced by $P$. freudenreichii 109 , determined by using native and partially acid-hydrolyzed EPS, and applying monosaccharide analysis, methylation analysis, mass spectrometry, and, in particular, NMR spectroscopy. For comparison, structural studies have also been carried out on two other propionibacteria strains, $P$. freudenreichii 111 and $P$. thoenii 126.

\section{Results and discussion}

\subsection{Isolation, purification, and composition of the exopolysaccharides}

It is generally known that the growth and EPS production of propionibacteria is improved by the addition of yeast extract to the culture medium. However, a disadvantage of this approach is the high contamination of the isolated EPS with high-molecular-mass (gluco)mannans, which are not eliminated by dialysis. ${ }^{17}$ To overcome this inconvenience, yeast extract powder was dissolved in water, then ultrafiltered (10-kDa cut off), and the filtrate was used as an additive to the wheybased medium. Following this protocol, the EPSs produced by the three propionibacteria strains were isolated by ethanol precipitation from the culture supernatant, and coded EPS 109 for $P$. freudenreichii 109, EPS 111 for $P$. freudenreichii 111, and EPS 126 for $P$. thoenii 126. Each EPS was extensively dialyzed and subsequently lyophilized. The total yield of the three EPSs was about $500 \mathrm{mg} / \mathrm{L}$ of EPS 109, $250 \mathrm{mg} / \mathrm{L}$ of EPS 126, and $400 \mathrm{mg} / \mathrm{L}$ of EPS 111. The amount of protein in the EPS samples was less than $2 \%(\mathrm{w} / \mathrm{w})$. The high purity of the EPSs was indicated by a carbohydrate content of $>97 \%(\mathrm{w} / \mathrm{w})$ and by ${ }^{1} \mathrm{H}$ NMR spectroscopy (vide infra). Although phosphate has been reported ${ }^{13}$ as a constituent of a propionibacterium EPS, noncarbohydrate constituents, including sulfate and phosphate, were not found (or must be less than $2 \% \mathrm{w} / \mathrm{w}$ ) in EPS 109, 111, and 126.

Monosaccharide analysis, including the determination of absolute configurations, of native EPS 109, 111, and 126, revealed the presence of D-glucose (Glc), D-mannose (Man), and D-glucuronic acid (GlcA) in molar ratios of $2: 2: 1$.

Methylation analysis (partially methylated alditol acetates (PMAAs); GLC-EIMS) of native EPS 109, 111, and 126 (Table 1) demonstrated the presence of terminal Glc $p$, 3-substituted Glc $p$ and 3,6-disubstituted Man $p$ in molar ratios of 1:1:2. The PMAAs of Glc and Man were verified using authentic standards. Because GlcA cannot
Table 1. Methylation analysis (linkage analysis) data of propionibacteria EPSs

\begin{tabular}{|c|c|c|c|c|}
\hline \multirow[t]{2}{*}{ Linkage type } & \multirow[t]{2}{*}{ Residue } & \multicolumn{3}{|c|}{ Molar ratio } \\
\hline & & EPS 109 & EPS 111 & EPS 126 \\
\hline $\operatorname{Hex} p(1-$ & Glc & 1.1 & 1.2 & 1.0 \\
\hline $\operatorname{HexpA}\left(1-^{\mathrm{a}}\right.$ & GlcA & 0.9 & 0.8 & 0.7 \\
\hline -3)Неxp(1- & Glc & 1.0 & 0.9 & 1.0 \\
\hline -3)Неxp(1- & Man & 0.2 & 0.1 & 0.2 \\
\hline -6)Неxp(1- & Glc & Trace & Trace & Trace \\
\hline$-3,6) \mathrm{Hexp}(1-$ & Man & 2.0 & 2.0 & 2.0 \\
\hline
\end{tabular}

${ }^{\text {a }}$ Determined after methanolysis of permethylated EPS.

be recovered as PMAA, terminal GlcpA was determined by GLC-EIMS after methanolysis of the permethylated polysaccharide (molar ratio terminal Glcp and terminal Glc $p \mathrm{~A}$ is $1: 1)$. The data so far indicate a branched pentasaccharide repeating unit for each EPS. The finding of small amounts of 3-substituted Man probably reflects some heterogeneity in the polysaccharide backbone.

Since all three EPSs showed a very high viscosity, it was not possible to prepare $\mathrm{D}_{2} \mathrm{O}$ samples of native EPS of suitable concentration for NMR analysis. Therefore, in order to reduce the viscosity before NMR analysis, the three native EPSs were subjected to a very mild acid hydrolysis $\left(0.2 \mathrm{M} \mathrm{TFA}, 30 \mathrm{~min}, 100^{\circ} \mathrm{C}\right)$. The $1 \mathrm{D}$ ${ }^{1} \mathrm{H}$ NMR spectra $(300 \mathrm{~K})$ of EPS 109, 111, and 126 are depicted in Figure 1. The five monosaccharide units were arbitrarily labeled $\mathbf{A}-\mathbf{E}$ according to the decreasing chemical shift values of their anomeric protons. The anomeric region $\left(\delta_{\mathrm{H}} 4.4-5.5\right)$ in the ${ }^{1} \mathrm{H}$ NMR spectra contained three well-resolved signals $(\mathbf{C}, \mathbf{D}, \mathbf{E})$ and two overlapping signals $(\mathbf{A}, \mathbf{B})$, corresponding with a suggested pentasaccharide repeating unit. The overlap of the anomeric signals (A, B) was confirmed by 2D TOCSY spectra and ${ }^{13} \mathrm{C}-{ }^{1} \mathrm{H}$ HSQC experiments (vide infra). Based on observed ${ }^{1} \mathrm{H}$ chemical shifts and ${ }^{3} J_{1,2}$ coupling constant values, residues $\mathbf{A}, \mathbf{B}, \mathbf{C}$, and $\mathbf{D}$ $\left({ }^{3} J_{1,2}<4 \mathrm{~Hz}\right)$ were allocated the $\alpha$-pyranose anomeric configuration, and residue $\mathbf{E}\left({ }^{3} J_{1,2} 8.5 \mathrm{~Hz}\right)$ was assigned the $\beta$-pyranose anomeric configuration. This coding system will also be used in the analysis of the oligosaccharide fragments (see Sections 2.2 and 2.3, detailed structural analysis of EPS 109).

According to the great similarities in monosaccharide and methylation analysis, and the identical $1 \mathrm{D}{ }^{1} \mathrm{H}$ NMR spectra, it can tentatively be concluded that the three EPSs have identical primary structures.

\subsection{Oligosaccharides obtained by partial acid hydrolysis of EPS 109}

To prepare a series of suitable oligosaccharide fragments, native EPS 109 was hydrolyzed in $0.5 \mathrm{M}$ TFA at $100{ }^{\circ} \mathrm{C}$. The progress of the partial acid hydrolysis was followed by analyzing aliquots on TLC, and the 

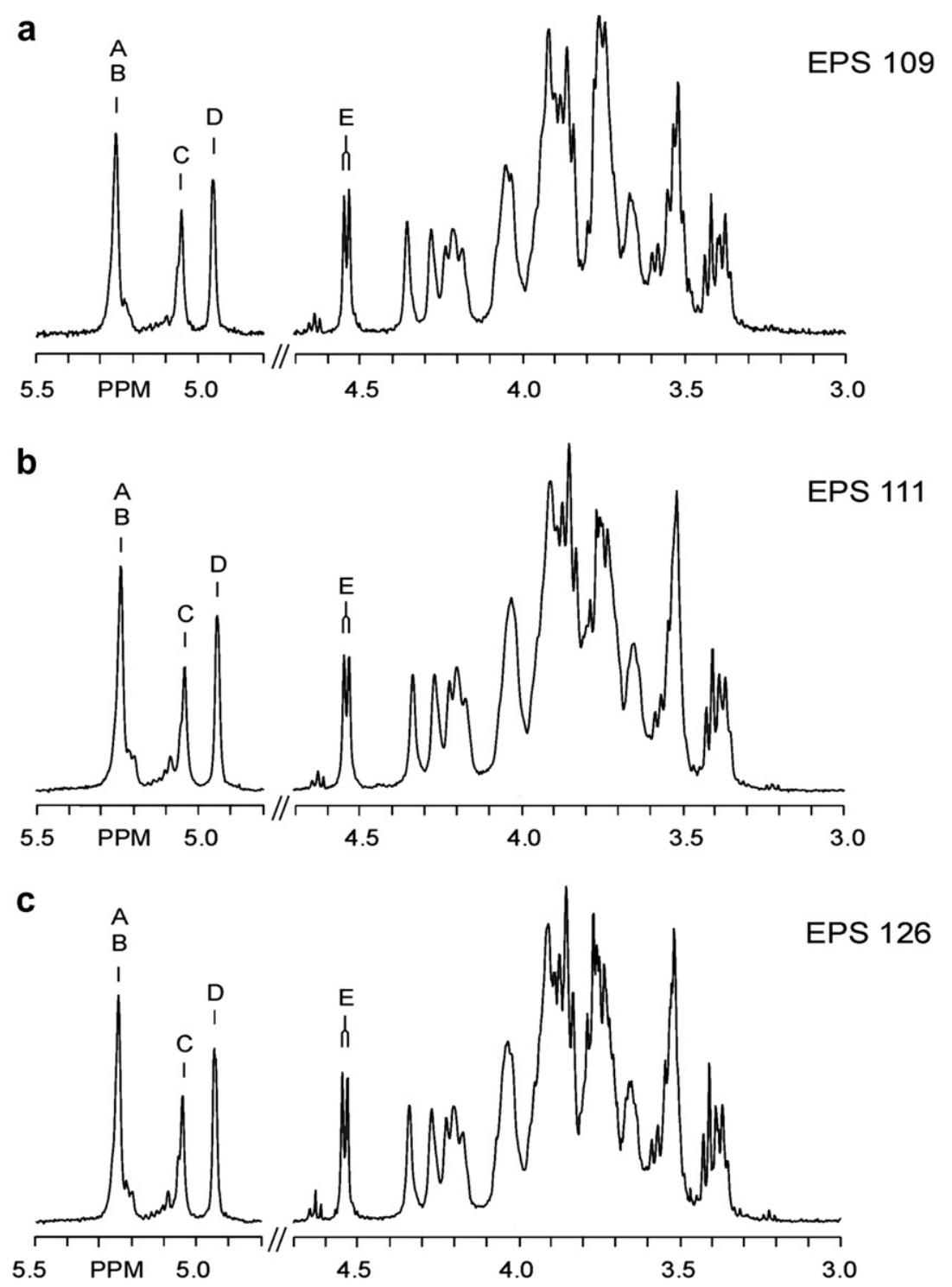

Figure 1. 500-MHz 1D ${ }^{1} \mathrm{H}$ NMR spectra of EPS produced by (a) Propionibacterium freudenreichii 109, (b) Propionibacterium freudenreichii 111, and (c) Propionibacterium thoenii 126, recorded in $\mathrm{D}_{2} \mathrm{O}$ at $300 \mathrm{~K}$.

complex mixture of oligosaccharides, obtained after a 3-h incubation was fractionated on Bio-Gel P-2, yielding fractions I to VII (Fig. 2a). Bio-Gel P-2 fraction I contained free Glc and Man, and fractions VI and VII high-molecular-mass oligosaccharides, which were not further analyzed. Fractions II, III, IV, and half of the amount of fraction $\mathbf{V}$ were subfractionated by HPAEC on CarboPac PA-1 (Fig. 2b), and subfractions II.2, III.3, IV.4, V.5, V.6, and V.7 (showing one band on TLC) were used for detailed analysis. The other half of the amount of fraction $\mathbf{V}$ was reduced with $\mathrm{NaBH}_{4}$, prior to subfractionation on CarboPac PA-1 (Fig. 2c). In the latter case, subfractions V.a, V.b, and V.c (showing one band on TLC) were selected for detailed analysis. Table 2 summarizes the monosaccharide and methylation analysis data of the selected fractions.
2.2.1. Fraction II.2. Monosaccharide analysis of fraction II.2 (Table 2) revealed the composition of Man and Glc in a molar ratio of 1:1, and methylation analysis (Table 2) demonstrated the presence of terminal Glc $p$ and 6-substituted $\operatorname{Man} p$, indicating a disaccharide Glc(1-6)Man.

The 1D ${ }^{1} \mathrm{H}$ NMR spectrum (Fig. 3a) showed three anomeric signals: $\delta_{\mathrm{H}} 5.180$ (residue $\mathbf{B} \alpha,{ }^{3} J_{1,2}<2 \mathrm{~Hz}$ ) and $\delta_{\mathrm{H}} 4.914$ (residue $\mathbf{B} \boldsymbol{\beta},{ }^{3} J_{1,2}<2 \mathrm{~Hz}$ ), both attributed to a reducing-end $\operatorname{Man} p$ residue, and $\delta_{\mathrm{H}} 4.954 / 4.959$ (residue $\mathbf{D}_{\alpha} / \mathbf{D}_{\boldsymbol{\beta}},{ }^{3} J_{1,2} 3.6 \mathrm{~Hz}$ ), assigned to an $\alpha$-Glc $p$ residue. The twinning observed for the Glc H-1 signal is due to the influence of the $\alpha / \beta$ configuration of the reducing-end Man residue. The assignments of all ${ }^{1} \mathrm{H}$ and ${ }^{13} \mathrm{C}$ resonances of $\mathbf{I I . 2}$, as obtained from 2D TOC$\mathrm{SY}$ and ${ }^{13} \mathrm{C}-{ }^{1} \mathrm{H}$ HSQC experiments (spectra not shown), 

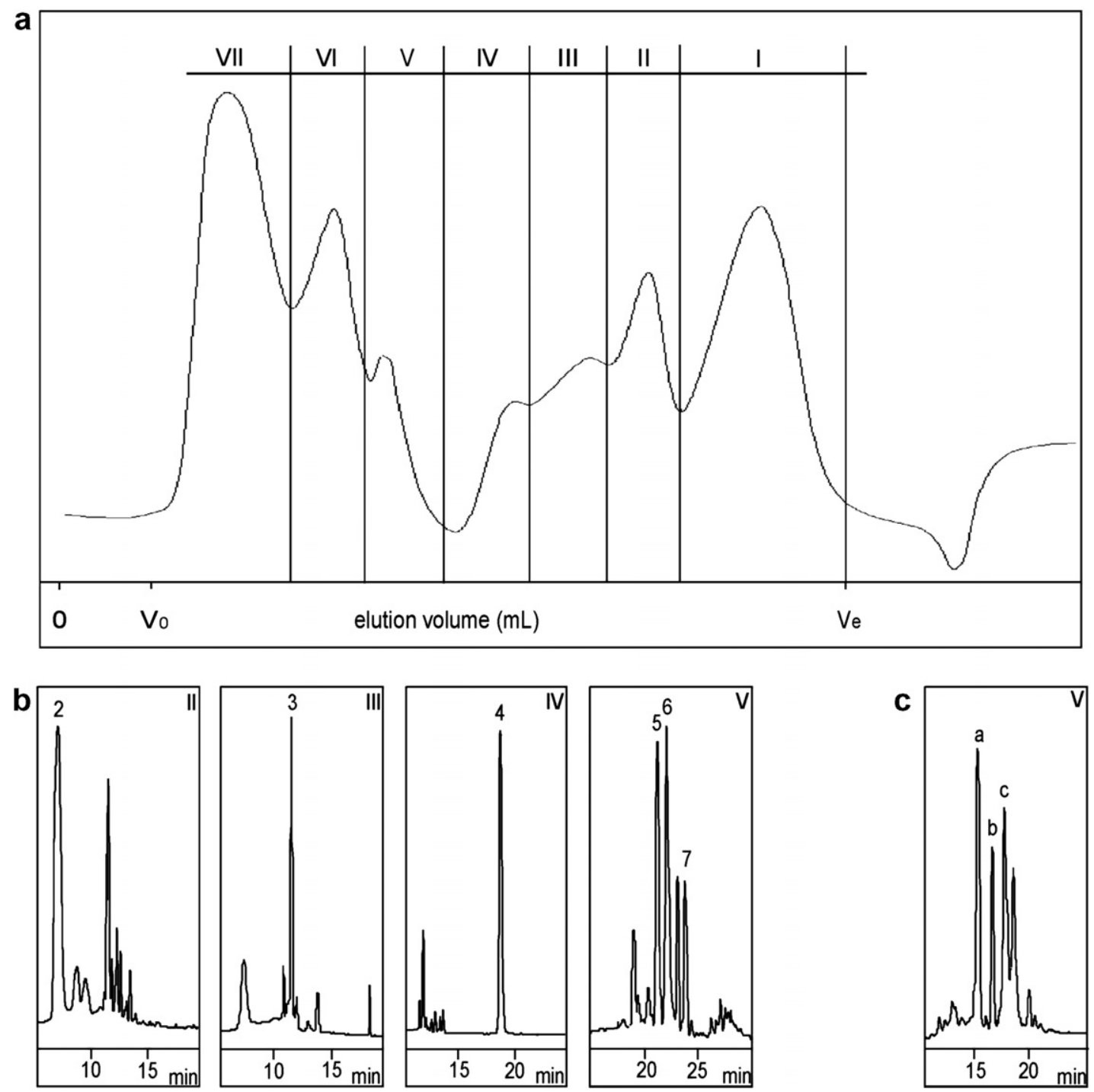

Figure 2. (a) Bio-Gel P-2 elution profile, monitored by refractive index detection, of partially acid-hydrolyzed EPS 109; (b) HPAEC-PAD fractionation patterns of Bio-Gel P-2 fractions II-V on CarboPac PA-1; (c) HPAEC-PAD fractionation pattern of reduced Bio-Gel P-2 fraction V on CarboPac PA-1. For elution conditions, see Section 3.3.

Table 2. Monosaccharide and methylation analysis data of oligosaccharides(-alditols) derived from EPS 109

\begin{tabular}{|c|c|c|c|c|c|c|c|c|c|}
\hline \multirow[t]{2}{*}{ Monosaccharide/linkage type } & \multicolumn{9}{|c|}{ Molar ratio } \\
\hline & II.2 & III.3 & IV.4 & V.5 & V.6 & V.7 & V.a & V.b & $\overline{\text { V.c }}$ \\
\hline Man & 1.0 & 1.0 & 2.0 & 2.0 & 2.0 & 2.0 & 1.0 & 2.0 & 2.0 \\
\hline Glc & 1.1 & 0.3 & 0.1 & 1.1 & 2.3 & 2.2 & 1.0 & 1.0 & 2.1 \\
\hline GlcA & - & 0.9 & 0.9 & 0.8 & 1.0 & 0.8 & 0.7 & 0.7 & 0.9 \\
\hline Man-ol & - & - & - & - & - & - & 0.7 & $\operatorname{tr}^{\mathrm{b}}$ & $\operatorname{tr}$ \\
\hline Glc-ol & - & - & - & - & - & - & - & 0.8 & 0.8 \\
\hline Glcp $p(1-$ & 1.0 & 0.1 & $\operatorname{tr}$ & - & 0.8 & 2.0 & 0.7 & 1.0 & 1.9 \\
\hline $\operatorname{Glcp} \mathrm{A}\left(1-^{\mathrm{a}}\right.$ & - & 0.7 & 0.8 & 0.7 & 0.8 & 0.8 & 1.0 & 0.8 & 0.8 \\
\hline -3)Glcp(1- & - & - & - & 0.9 & 0.8 & - & - & - & - \\
\hline -3)Manp(1- & - & - & 0.9 & 0.9 & - & $\operatorname{tr}$ & - & $\operatorname{tr}$ & $\operatorname{tr}$ \\
\hline -6)Manp(1- & 0.8 & 1.0 & 1.0 & 1.0 & 1.0 & $\operatorname{tr}$ & 1.0 & 1.0 & $\operatorname{tr}$ \\
\hline -6)Glcp(1- & - & - & - & - & - & $\operatorname{tr}$ & - & - & - \\
\hline$-3,6) \operatorname{Man} p(1-$ & - & 0.1 & - & - & 1.0 & 1.7 & $\operatorname{tr}$ & 1.0 & 2.0 \\
\hline -3,6)Man-ol & - & - & - & - & - & - & 1.0 & - & - \\
\hline-3$)$ Glc-ol & - & - & - & - & - & - & - & 0.7 & 0.9 \\
\hline
\end{tabular}

${ }^{a}$ Determined after methanolysis of the permethylated oligosaccharide(-alditol).

${ }^{\mathrm{b}} \operatorname{tr}=$ trace. 


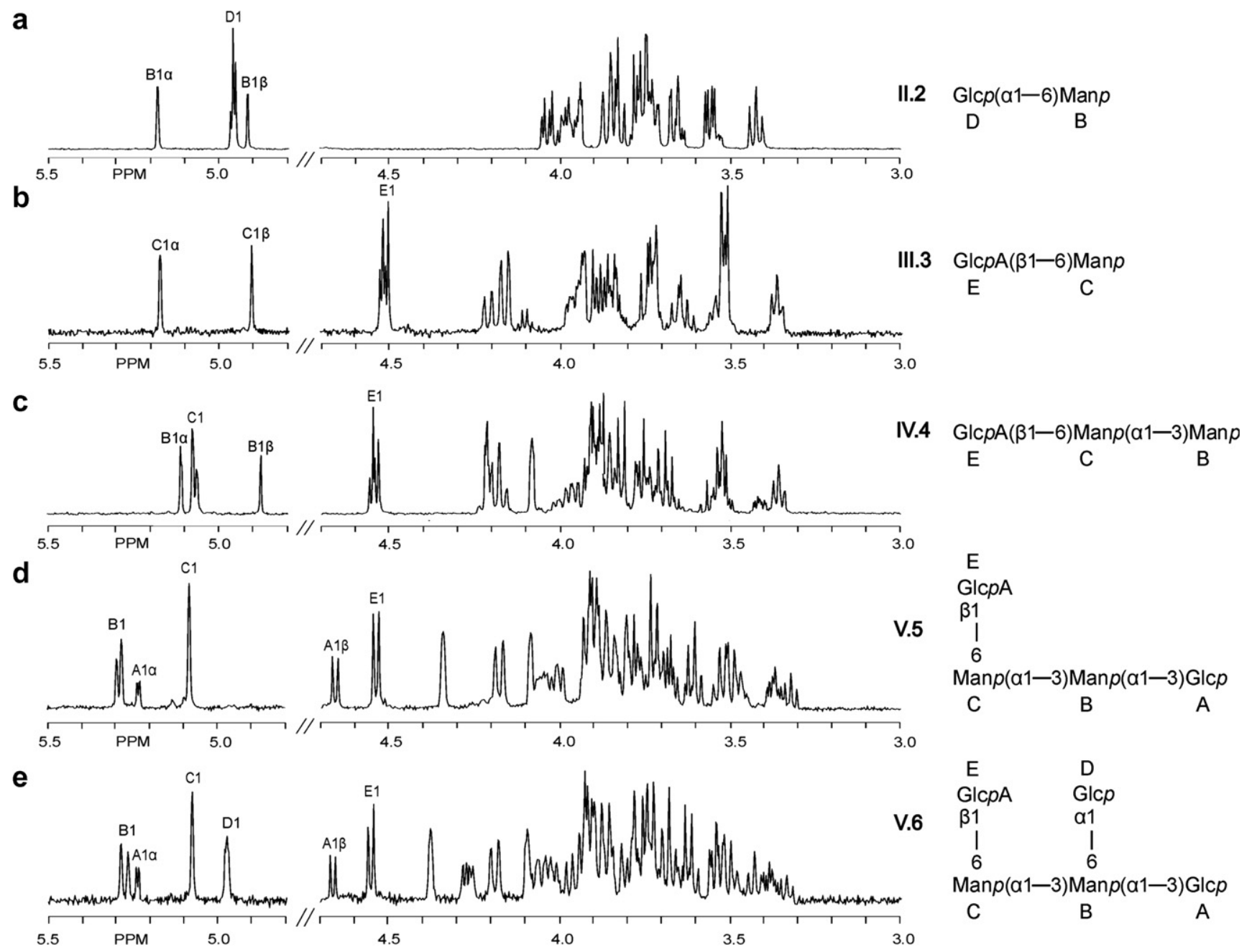

Figure 3. 500-MHz 1D ${ }^{1} \mathrm{H}$ NMR spectra of oligosaccharides(-alditols) derived from EPS 109, recorded in $\mathrm{D}_{2} \mathrm{O}$ at $300 \mathrm{~K}$. The chemical structures of the oligosaccharides(-alditols), including the annotation of the constituent residues, are depicted. D1 means H-1 of residue D, etc.

are presented in Table 3. The (1-6) linkage between residues $\mathbf{D}$ and $\mathbf{B}$ is supported by the downfield position of Man-B C-6 ( $\left.\delta_{\mathrm{C}-6} 68.7\right)$ and the inter-residue ROESY cross-peaks (spectrum not shown) between Glc-D H-1 $\left(\delta_{\mathrm{H}} 4.96\right)$ and Man-B $\alpha$ H-6a/6b $\left(\delta_{\mathrm{H}} 4.04 / 3.67\right)$, ManB $\beta$ H-6a/6b $\left(\delta_{\mathrm{H}} 3.98 / 3.67\right)$.

From these data, it can be concluded that fraction II.2 contained the following disaccharide:

$$
\begin{array}{cc}
\alpha-\mathrm{D}-\mathrm{Glc} p-(1 \rightarrow 6)-\mathrm{D}-\mathrm{Man} p \\
\mathbf{D} & \mathbf{B}
\end{array}
$$

2.2.2. Fraction III.3. According to the monosaccharide analysis (Table 2), fraction III.3 contained a disaccharide as the major component, consisting of Man and GlcA in a molar ratio of 1:1. Methylation analysis (Table 2) revealed the presence of terminal GlcpA and 6-substituted Manp, suggesting a disaccharide GlcA(1-6)Man.

The 1D ${ }^{1} \mathrm{H}$ NMR spectrum (Fig. 3b) showed three anomeric signals: $\delta_{\mathrm{H}} 5.174$ (residue $\mathbf{C} \alpha,{ }^{3} J_{1,2}<2 \mathrm{~Hz}$ ) and $\delta_{\mathrm{H}} 4.905$ (residue $\mathbf{C} \boldsymbol{\beta},{ }^{3} J_{1,2}<2 \mathrm{~Hz}$ ), both attributed to a reducing-end $\operatorname{Man} p$ residue, and $\delta_{\mathrm{H}} 4.511 / 4.518$ (residue $\mathbf{E}_{\boldsymbol{\alpha}} / \mathbf{E}_{\boldsymbol{\beta}},{ }^{3} J_{1,2} 7.9 \mathrm{~Hz}$ ), assigned to a $\beta$-GlcpA residue. The twinning observed for the GlcA H-1 signal is due to the influence of the $\alpha / \beta$ configuration of the reducing-end Man residue. The assignments of all ${ }^{1} \mathrm{H}$ and ${ }^{13} \mathrm{C}$ resonances of III.3 were obtained from $2 \mathrm{D}$ TOCSY and ${ }^{13} \mathrm{C}-{ }^{1} \mathrm{H}$ HSQC experiments (spectra not shown), and are presented in Table 3 . The (1-6) linkage between residues $\mathbf{E}$ and $\mathbf{C}$ is evidenced by the downfield position of Man-C C-6 $\left(\delta_{\mathrm{C}-6} 71.8 / 72.0\right)$ as well as the inter-residue ROESY cross-peaks (spectrum not shown) between GlcA-E H-1 $\left(\delta_{\mathrm{H}} 4.52\right)$ and Man-C $\boldsymbol{\alpha} \mathrm{H}-6 \mathrm{a} / 6 \mathrm{~b}$ $\left(\delta_{\mathrm{H}} 4.16 / 3.88\right)$, Man-C $\boldsymbol{\beta} \mathrm{H}-6 \mathrm{a} / 6 \mathrm{~b}\left(\delta_{\mathrm{H}} 4.21 / 3.84\right)$.

Combination of the data leads to the conclusion that fraction III.3 contained the following disaccharide: 


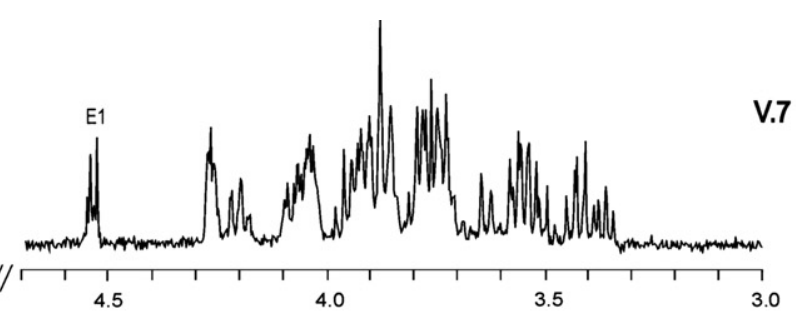

.7

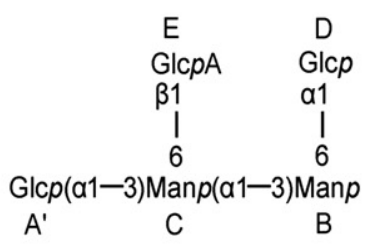

g
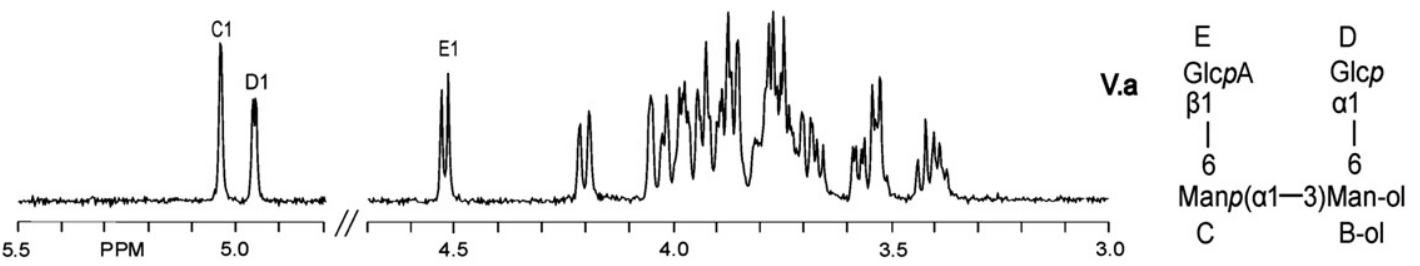

h
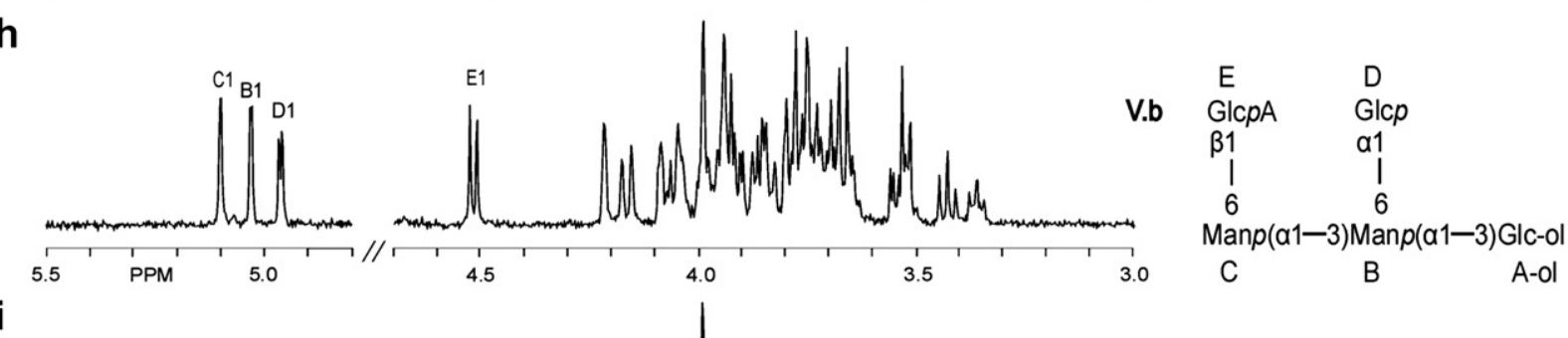

$$
\text { i }
$$
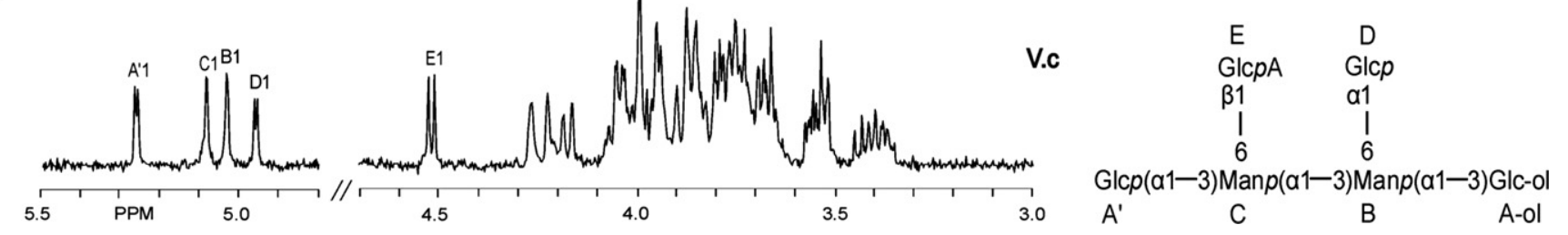

Figure 3 (continued)

$$
\begin{array}{cc}
\beta \text {-D-GlcpA-(1 } \rightarrow 6)-\mathrm{D}-\mathrm{Man} p \\
\mathbf{E} & \mathbf{C}
\end{array}
$$

2.2.3. Fraction IV.4. Monosaccharide analysis in combination with methylation analysis of fraction IV.4 demonstrated the presence of terminal GlcpA, 6-substituted Man $p$, and 3-substituted Man $p$ (Table 2) in equal molar ratios, indicating a linear trisaccharide.

The 1D ${ }^{1} \mathrm{H}$ NMR spectrum of fraction IV.4 is presented in Figure 3c. The assignments of all ${ }^{1} \mathrm{H}$ and ${ }^{13} \mathrm{C}$ resonances followed from 2D TOCSY and ${ }^{13} \mathrm{C}-{ }^{1} \mathrm{H}$ HSQC experiments (spectra not shown), and are presented in Tables 4 and 5 , respectively. Anomeric ${ }^{1} \mathrm{H}$ signals were observed at $\delta_{\mathrm{H}} 5.130$ (reducing-end $\operatorname{Man} p-\mathbf{B} \boldsymbol{\alpha}$, ${ }^{3} J_{1,2}<2 \mathrm{~Hz}$ ) and $\delta_{\mathrm{H}} 4.900$ (reducing-end Man $p-\mathbf{B} \beta,{ }^{3} J_{1,2}$ $<2 \mathrm{~Hz})$, at $\delta_{\mathrm{H}} 5.085 / 5.073\left(\alpha \operatorname{Man} p-\mathbf{C}_{\alpha / \beta},{ }^{3} J_{1,2}<2 \mathrm{~Hz}\right)$, and at $\delta_{\mathrm{H}} 4.533 / 4.537\left(\beta \mathrm{Glc} p \mathrm{~A}-\mathbf{E}_{\alpha / \beta},{ }^{3} J_{1,2} 7.3 \mathrm{~Hz}\right)$. The twinnings observed for the $\mathbf{C} \mathrm{H}-1$ and $\mathbf{E ~ H}-1$ signals are due to the $\alpha / \beta$ anomers of the reducing-end Man residue. Integration of the anomeric signals demonstrated a B:C:E molar ratio of $1: 1: 1$. In view of the established structure, for comparison, reference ${ }^{1} \mathrm{H}$ and ${ }^{13} \mathrm{C}$ data deduced from 2D TOCSY $(200 \mathrm{~ms})$ and ${ }^{13} \mathrm{C}-{ }^{1} \mathrm{H}$ HSQC

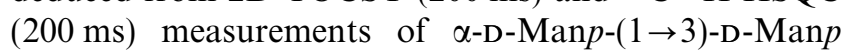

have been incorporated in Tables 4 and 5 . The ${ }^{13} \mathrm{C}$ data of IV.4 clearly reflect the 3 -substitution of Man-B $\left[\delta_{\mathrm{C}-3}\right.$ $81.4(\alpha)$ and $84.0(\beta) ; \Delta \delta \sim+10 \mathrm{ppm}$ compared to free Man, $\delta_{\mathrm{C}-3} 71.3(\alpha)$ and $\left.74.1(\beta)^{18,19}\right]$, and the 6-substitution of Man-C $\left(\delta_{\mathrm{C}-6} 71.8 ; \Delta \delta+9.7 \mathrm{ppm}\right.$ compared to $\left.\alpha \mathrm{Man} p 1 \mathrm{Me}, \quad \delta_{\mathrm{C}-6} \quad 62.1^{18,19}\right)$. Inter-residue ROESY cross-peaks (spectrum not shown) between Man-C H-1 $\left(\delta_{\mathrm{H}} 5.08\right)$ and Man-B H-3 $\left[\delta_{\mathrm{H}} 3.91(\alpha) / 3.72(\beta)\right]$ indicated a $\mathbf{C}(1 \rightarrow 3)$ B linkage, and between GlcA-E H-1 $\left(\delta_{\mathrm{H}} 4.53\right)$ and Man-C H-6a/6b $\left(\delta_{\mathrm{H}} 4.18 / 3.91\right)$ an $\mathbf{E}(1 \rightarrow 6) \mathbf{C}$ linkage.

Based on these data, the structure of the trisaccharide in fraction IV.4 can be formulated as

$$
\begin{array}{ccc}
\beta-\mathrm{D}-\mathrm{Glc} p \mathrm{~A}-(1 \rightarrow 6)-\alpha-\mathrm{D}-\mathrm{Man} p-(1 \rightarrow 3)-\mathrm{D}-\mathrm{Man} p \\
\mathbf{E} & \mathbf{C} & \mathbf{B}
\end{array}
$$

2.2.4. Fraction V.5. MALDI-TOFMS analysis of fraction $\mathbf{V . 5}$ showed a $[\mathrm{M}-\mathrm{H}+2 \mathrm{Na}]^{+}$pseudomolecular ion at $\mathrm{m} / \mathrm{z}$ 725.8, corresponding with $\mathrm{HexAHex}_{3}$ $(M=680 \mathrm{Da})$. Monosaccharide analysis revealed the presence of GlcA, Man, and Glc in a molar ratio of $1: 2: 1$, whereas methylation analysis showed the presence 
Table 3. ${ }^{1} \mathrm{H}$ NMR and ${ }^{13} \mathrm{C}$ NMR chemical shifts ${ }^{\mathrm{a}}$ of disaccharides II.2 $(\mathbf{D} \rightarrow \mathbf{B})$ and III.3 $(\mathbf{E} \rightarrow \mathbf{C})$, derived from EPS 109, recorded in $\mathrm{D}_{2} \mathrm{O}$ at $300 \mathrm{~K}$

\begin{tabular}{|c|c|c|c|c|c|c|}
\hline Residue & Proton & II. 2 & III.3 & Carbon & II. 2 & III.3 \\
\hline $\operatorname{Man}-\mathbf{B} \boldsymbol{\alpha}$ & $H-1 \alpha$ & 5.180 & 5.174 & $C-1(\alpha)$ & 97.1 & 97.2 \\
\hline (II.2) & $\mathrm{H}-2$ & 3.94 & 3.94 & $\mathrm{C}-2$ & 73.5 & 73.9 \\
\hline Man-C $\boldsymbol{\alpha}$ & $\mathrm{H}-3$ & 3.84 & 3.84 & C-3 & 73.4 & 73.5 \\
\hline \multirow{4}{*}{ (III.3) } & H-4 & 3.81 & 3.73 & C-4 & 69.5 & 69.5 \\
\hline & H-5 & 3.98 & 3.96 & C-5 & 73.5 & 74.8 \\
\hline & H-6a & 4.04 & 4.16 & C-6 & 68.7 & 71.8 \\
\hline & H-6b & 3.67 & 3.88 & & & \\
\hline Man-Bß & $\mathrm{H}-1 \beta$ & 4.914 & 4.905 & $C-1(\beta)$ & 96.7 & 97.0 \\
\hline (II.2) & $\mathrm{H}-2$ & 3.96 & 3.95 & $\mathrm{C}-2$ & 73.9 & 74.8 \\
\hline Man-C $\boldsymbol{\beta}$ & $\mathrm{H}-3$ & 3.64 & 3.64 & $\mathrm{C}-3$ & 76.1 & 76.5 \\
\hline \multirow[t]{4}{*}{ (III.3) } & $\mathrm{H}-4$ & 3.72 & 3.63 & C-4 & 69.0 & 69.2 \\
\hline & H-5 & 3.53 & 3.54 & C-5 & 77.3 & 78.0 \\
\hline & H-6a & 3.98 & 4.21 & C-6 & 68.7 & 72.0 \\
\hline & H-6b & 3.67 & 3.84 & & & \\
\hline \multirow[t]{7}{*}{ Glc-D } & $\mathrm{H}-1$ & $4.954 / 9^{b}$ & - & C-1 & 100.8 & - \\
\hline & $\mathrm{H}-2$ & 3.56 & - & $\mathrm{C}-2$ & 74.4 & - \\
\hline & $\mathrm{H}-3$ & 3.76 & - & C-3 & 76.0 & - \\
\hline & $\mathrm{H}-4$ & 3.43 & - & C-4 & 72.4 & - \\
\hline & H-5 & 3.74 & - & C-5 & 74.6 & - \\
\hline & H-6a & 3.85 & - & C-6 & 63.2 & - \\
\hline & $\mathrm{H}-6 \mathrm{~b}$ & 3.77 & - & & & \\
\hline \multirow[t]{6}{*}{ GlcA-E } & $\mathrm{H}-1$ & - & $4.511 / 8^{b}$ & C-1 & - & 105.6 \\
\hline & $\mathrm{H}-2$ & - & 3.36 & $\mathrm{C}-2$ & - & 76.5 \\
\hline & $\mathrm{H}-3$ & - & 3.52 & C-3 & - & 78.3 \\
\hline & H-4 & - & 3.52 & C-4 & - & 74.9 \\
\hline & H-5 & - & 3.72 & C-5 & - & 79.0 \\
\hline & & & & C-6 & - & 178.4 \\
\hline
\end{tabular}

${ }^{\mathrm{a}}$ In ppm relative to the signal of internal acetone $\left(\delta 2.225\right.$ for ${ }^{1} \mathrm{H}, \delta$ 31.07 for ${ }^{13} \mathrm{C}$ ).

${ }^{\mathrm{b}}$ Differences in last decimal due to splitting of the resonance signal (see text).

of terminal GlcpA, 3-substituted Glcp, 3-substituted Man $p$, and 6-substituted Man $p$ (Table 2). Taking together these data, a linear tetrasaccharide is indicated.

The 1D ${ }^{1} \mathrm{H}$ NMR spectrum of fraction V.5 is depicted in Figure 3d. The assignments of all ${ }^{1} \mathrm{H}$ and ${ }^{13} \mathrm{C}$ resonances, obtained from $2 \mathrm{D}$ TOCSY and ${ }^{13} \mathrm{C}-{ }^{1} \mathrm{H}$ HSQC experiments (spectra not shown), are presented in Tables 4 and 5 , respectively. Five anomeric ${ }^{1} \mathrm{H}$ signals are present at $\delta_{\mathrm{H}} 5.292 / 5.278\left(\alpha \operatorname{Man} p-\mathbf{B}_{\alpha / \boldsymbol{\beta}}\right), \delta_{\mathrm{H}} 5.230$ (reducingend Glcp-A $\left.\alpha,{ }^{3} J_{1,2} 3.6 \mathrm{~Hz}\right), \delta_{\mathrm{H}} 5.079(\alpha \operatorname{Man} p-\mathbf{C}), \delta_{\mathrm{H}}$ 4.658 (reducing-end Glcp-A $\boldsymbol{\beta},{ }^{3} J_{1,2} 8.5 \mathrm{~Hz}$ ), and $\delta_{\mathrm{H}}$ 4.541 (terminal $\beta$-GlcpA-E, ${ }^{3} J_{1,2} 8.5 \mathrm{~Hz}$; compare with IV.4). The twinning observed for the $\mathbf{B}$ H-1 signal is due to the $\alpha / \beta$ anomers of the reducing-end Glc residue. The ${ }^{13} \mathrm{C}$ data of V.5 indicate a 6 -substituted Man-C $\left(\delta_{\mathrm{C}-6}\right.$ $71.5 ; \Delta \delta+9.4 \mathrm{ppm}$ compared to $\alpha \operatorname{Man} p 1 \mathrm{Me}, \delta_{\mathrm{C}-6}$ $\left.62.1^{18,19}\right)$, a 3-substituted Man-B $\left(\delta_{\mathrm{C}-3} \quad 81.5 ; \Delta \delta\right.$ $+9.7 \mathrm{ppm}$ compared to $\left.\alpha \operatorname{Man} p 1 \mathrm{Me}, \delta_{\mathrm{C}-3} \quad 71.8^{18,19}\right)$, and a 3 -substituted Glc-A $\left[\delta_{\mathrm{C}-3} 80.3(\alpha)\right.$ and $82.8(\beta)$; $\Delta \delta \sim+6.3 \mathrm{ppm}$ compared to free Glc, $\delta_{\mathrm{C}-3} 73.8(\alpha)$ and $76.7(\beta)^{18,19}$ ] residue. The sequence of the four monosaccharides followed from a ROESY analysis; here, the inter-residue connectivities GlcA-E H-1,Man-C H- 6a/6b, Man-C H-1,Man-B H-3, and Man-B H-1,Glc$\mathbf{A} \boldsymbol{\alpha} / \boldsymbol{\beta} \mathrm{H}-3$ reflect the $\mathbf{E}(1 \rightarrow 6) \mathbf{C}, \quad \mathbf{C}(1 \rightarrow 3) \mathbf{B}$, and $\mathbf{B}(1 \rightarrow 3) \mathbf{A}$ linkages, respectively.

In summary, it can be concluded that the structure of the tetrasaccharide in fraction V.5 is
$\beta$-D-GlcpA-( $1 \rightarrow 6)-\alpha-\mathrm{D}-\mathrm{Man} p-(1 \rightarrow 3)-\alpha-\mathrm{D}-\mathrm{Man} p-(1 \rightarrow 3)-\mathrm{D}-\mathrm{Gl} p p$
$\mathbf{E}$
C
B
A

2.2.5. Fraction V.6. MALDI-TOFMS analysis of fraction V.6 showed a $[\mathrm{M}-\mathrm{H}+2 \mathrm{Na}]^{+}$pseudomolecular ion at $m / z$ 887.9, corresponding with HexAHex 4 $(M=842 \mathrm{Da})$. Monosaccharide analysis demonstrated the occurrence of GlcA, Man, and Glc in a molar ratio of $1: 2: 2$, whereas methylation analysis revealed the presence of terminal GlcpA, terminal Glcp, 3-substituted Glc $p$, 6-substituted Manp, and 3,6-disubstituted Man $p$ (Table 2). Taking together these data, a branched pentasaccharide is indicated.

The anomeric region of the $1 \mathrm{D}{ }^{1} \mathrm{H}$ NMR spectrum of fraction V.6 (Fig. 3e) looks similar to that of V.5, with the exception of an extra anomeric signal at $\delta_{\mathrm{H}} 4.97$ (residue $\mathbf{D}_{\alpha / \boldsymbol{\beta}},{ }^{3} J_{1,2} \sim 3.7 \mathrm{~Hz}$, broad peak), which was attributed to an $\alpha \mathrm{Glc}$ residue. The ${ }^{1} \mathrm{H}$ chemical shifts of the remaining five anomeric signals (residues $\mathbf{A} \boldsymbol{\alpha}$, $\mathbf{A} \boldsymbol{\beta}, \mathbf{B}_{\boldsymbol{\alpha} / \boldsymbol{\beta}}, \mathbf{C}$, and $\mathbf{E}$ ) correspond closely to those found for V.5 (Table 4).

The assignments of the ${ }^{1} \mathrm{H}$ and ${ }^{13} \mathrm{C}$ resonances of the constituent monosaccharides of $\mathbf{V . 6}$ were performed by means of 2D TOCSY (mixing times built-up, 40$200 \mathrm{~ms}$ ) and $2 \mathrm{D}{ }^{13} \mathrm{C}-{ }^{1} \mathrm{H}$ HSQC experiments, and are presented in Tables 4 and 5, respectively. The TOCSY spectrum with a mixing time of $200 \mathrm{~ms}$ is shown in Figure 4, together with the HSQC and the ROESY (mixing time, $200 \mathrm{~ms}$ ) spectra. Starting points for the interpretation of the TOCSY spectra were the anomeric signals of the various residues. Comparison of these spectra with increasing mixing times allowed the assignment of the sequential order of the chemical shifts belonging to the same spin system. The TOCSY E H-1 track ( $\delta$ 4.543) showed the complete spin system $\mathrm{H}-1,2,3,4,5$, typical for a $\beta$ Glc $p$ A residue. ${ }^{18,20}$ The $\alpha \operatorname{Man} p-\mathbf{C ~ H}-1$ track $(\delta$ 5.077) allowed the observation of cross-peaks with $\mathbf{C}$ $\mathrm{H}-2$ and $\mathrm{H}-3$, whereas the remaining signals could be found via $\mathbf{C ~} \mathbf{H}-2$ on the $\mathbf{C ~ H - 6 a}$ track. The assignment of the resonances belonging to the $\alpha \operatorname{Man} p-\mathbf{B}$ residue started on the H-1 track ( $\delta 5.27)$, and continued via the H-2 and H-5 tracks. The D H-1 track ( $\delta$ 4.97) showed cross-peaks with D H-2,3,4,5, corresponding with the ${ }^{1} \mathrm{H}$ values for residue $\mathbf{D}$ in $\mathbf{I I . 2}$, indicating a terminal $\alpha \mathrm{Glc} p$ residue, ${ }^{18,19}$ the $\mathbf{D} \mathrm{H}-6 \mathrm{a}, 6 \mathrm{~b}$ values were deduced from the HSQC spectrum. On the Glcp-A $\alpha$ H-1 track ( $\delta$ 5.232) cross-peaks with $\mathbf{A} \boldsymbol{\alpha}$ H-2 and H-3 could be detected; the resonances for $\mathbf{A} \alpha \mathrm{H}-5,6 \mathrm{a}, 6 \mathrm{~b}$ followed from 
Table 4. ${ }^{1} \mathrm{H}$ NMR chemical shifts ${ }^{\mathrm{a}}$ of EPS 109, and of oligosaccharides obtained from a partial acid hydrolysate of EPS 109, recorded in $\mathrm{D}_{2} \mathrm{O}$ at $300 \mathrm{~K}$

\begin{tabular}{|c|c|c|c|c|c|c|c|}
\hline Residue & Proton & $\mathrm{MM}^{\mathrm{b}}$ & IV.4 & V.5 & V.6 & V.7 & EPS 109 \\
\hline \multirow[t]{2}{*}{ Glc-A $\alpha$} & $\mathrm{H}-1$ & - & - & 5.230 & 5.232 & $5.262 / 75$ & 5.260 \\
\hline & $\mathrm{H}-2$ & - & - & 3.62 & 3.62 & 3.55 & 3.65 \\
\hline \multirow[t]{5}{*}{ Glc-A' (V.7) } & $\mathrm{H}-3$ & - & - & 3.90 & 3.90 & 3.78 & 3.93 \\
\hline & $\mathrm{H}-4$ & - & - & 3.76 & n.d. ${ }^{\mathrm{c}}$ & 3.40 & 3.58 \\
\hline & $\mathrm{H}-5$ & - & - & 3.85 & 3.86 & 3.86 & 3.87 \\
\hline & H-6a & - & - & 3.87 & 3.87 & 3.87 & 3.87 \\
\hline & H-6b & - & - & 3.77 & 3.77 & 3.77 & 3.76 \\
\hline \multirow[t]{7}{*}{ Glc-A $\beta$} & $\mathrm{H}-1$ & - & - & 4.658 & 4.658 & - & - \\
\hline & $\mathrm{H}-2$ & - & - & 3.33 & 3.33 & - & - \\
\hline & $\mathrm{H}-3$ & - & - & 3.68 & 3.68 & - & - \\
\hline & $\mathrm{H}-4$ & - & - & 3.62 & 3.62 & - & - \\
\hline & $\mathrm{H}-5$ & - & - & 3.47 & 3.47 & - & - \\
\hline & H-6a & - & - & 3.86 & 3.86 & - & - \\
\hline & H-6b & - & - & 3.77 & 3.77 & - & - \\
\hline \multirow{6}{*}{$\operatorname{Man}-\mathbf{B} \boldsymbol{\alpha}$} & $\mathrm{H}-2$ & 4.08 & 4.21 & 4.34 & 4.37 & 4.26 & 4.36 \\
\hline & $\mathrm{H}-3$ & 3.95 & 3.91 & 3.91 & 3.91 & 3.92 & 3.92 \\
\hline & $\mathrm{H}-4$ & 3.78 & 3.76 & 3.78 & 3.97 & 3.90 & 3.95 \\
\hline & $\mathrm{H}-5$ & 3.86 & 3.85 & 4.04 & 4.26 & 4.03 & 4.22 \\
\hline & H-6a & 3.89 & 3.88 & 3.87 & 4.06 & 4.08 & 4.05 \\
\hline & $\mathrm{H}-6 \mathrm{~b}$ & 3.76 & 3.75 & 3.75 & 3.67 & 3.95 & 3.67 \\
\hline \multirow[t]{7}{*}{ Man-B及 } & $\mathrm{H}-1$ & 4.908 & 4.900 & - & - & 4.925 & - \\
\hline & $\mathrm{H}-2$ & 4.08 & 4.21 & - & - & 4.25 & - \\
\hline & $\mathrm{H}-3$ & 3.76 & 3.72 & - & - & 3.74 & - \\
\hline & $\mathrm{H}-4$ & 3.69 & 3.70 & - & - & n.d. & - \\
\hline & $\mathrm{H}-5$ & 3.42 & 3.42 & - & - & n.d. & - \\
\hline & H-6a & 3.89 & 3.88 & - & - & 3.87 & - \\
\hline & H-6b & 3.76 & 3.75 & - & - & 3.63 & - \\
\hline \multirow[t]{5}{*}{ Man-C } & $\mathrm{H}-1$ & 5.136 & $5.073 / 85^{\mathrm{d}}$ & 5.079 & 5.077 & 5.078 & 5.056 \\
\hline & $\mathrm{H}-2$ & 4.07 & 4.08 & 4.09 & 4.09 & 4.26 & 4.28 \\
\hline & $\mathrm{H}-5$ & 3.78 & 3.98 & 4.00 & 4.02 & 4.04 & 4.05 \\
\hline & H-6a & 3.89 & 4.18 & 4.18 & 4.19 & 4.20 & 4.20 \\
\hline & H-6b & 3.76 & 3.91 & 3.91 & 3.94 & 3.94 & 3.93 \\
\hline \multirow[t]{7}{*}{ Glc-D } & $\mathrm{H}-1$ & - & - & - & 4.97 & $4.952 / 58$ & 4.964 \\
\hline & $\mathrm{H}-2$ & - & - & - & 3.55 & 3.54 & 3.55 \\
\hline & $\mathrm{H}-3$ & - & - & - & 3.78 & 3.78 & 3.77 \\
\hline & $\mathrm{H}-4$ & - & - & - & 3.42 & 3.43 & 3.42 \\
\hline & $\mathrm{H}-5$ & - & - & - & 3.73 & 3.74 & 3.73 \\
\hline & H-6a & - & - & - & 3.87 & 3.87 & 3.87 \\
\hline & $\mathrm{H}-6 \mathrm{~b}$ & - & - & - & 3.77 & 3.77 & 3.76 \\
\hline \multirow[t]{5}{*}{ GlcA-E } & $\mathrm{H}-1$ & - & $4.533 / 37^{\mathrm{d}}$ & 4.541 & 4.543 & $4.531 / 38^{d}$ & 4.541 \\
\hline & $\mathrm{H}-2$ & - & 3.36 & 3.37 & 3.37 & 3.36 & 3.38 \\
\hline & $\mathrm{H}-3$ & - & 3.52 & 3.53 & 3.53 & 3.52 & 3.53 \\
\hline & $\mathrm{H}-4$ & - & 3.52 & 3.52 & 3.52 & 3.52 & 3.53 \\
\hline & $\mathrm{H}-5$ & - & 3.78 & 3.73 & 3.73 & 3.73 & 3.72 \\
\hline
\end{tabular}

${ }^{\text {a }}$ In ppm relative to the signal of internal acetone at $\delta 2.225$.

${ }^{\mathrm{b}}$ Reference compound: $\operatorname{Man}(\alpha 1-3)$ Man.

${ }^{\mathrm{c}}$ n.d., not determined.

${ }^{\mathrm{d}}$ Difference in last two decimals due to signal splitting (see text).

the HSQC spectrum. Finally, on the Glc $p-\mathbf{A} \boldsymbol{\beta}$ H-1 track ( $\delta$ 4.658) all resonances except $\mathbf{A} \boldsymbol{\beta} \mathrm{H}-6 \mathrm{a}$, were identified. The latter was obtained from the vertical track. Note that $\mathbf{A} \boldsymbol{\beta} \mathrm{H}-2$ at the upfield position of $3.33 \mathrm{ppm}$ is characteristic for a reducing-end Glc $p$ residue. ${ }^{18,19}$
Taking into account published ${ }^{13} \mathrm{C}$ chemical shift data of (methyl) aldosides, ${ }^{18,19}$ the downfield chemical shifts of Man-B C-3 $\left(\delta_{\mathrm{C}-3} 81.5 ; \alpha \operatorname{Man} p 1 \mathrm{Me}, \delta_{\mathrm{C}-3} 71.8^{18,19}\right)$ and Glc-A $\alpha / \boldsymbol{\beta} \quad \mathrm{C}-3 \quad\left[\delta_{\mathrm{C}-3} \quad 80.0(\alpha) / 82.8(\beta) ;\right.$ Glc $p, \delta_{\mathrm{C}-3}$ $73.8(\alpha) / 76.7(\beta)^{18,19}$ ] demonstrated these residues to be 
Table 5. ${ }^{13} \mathrm{C}$ NMR chemical shifts ${ }^{\mathrm{a}}$ of EPS 109, and of oligosaccharides obtained from a partial acid hydrolysate of EPS 109, recorded in $\mathrm{D}_{2} \mathrm{O}$ at $300 \mathrm{~K}$

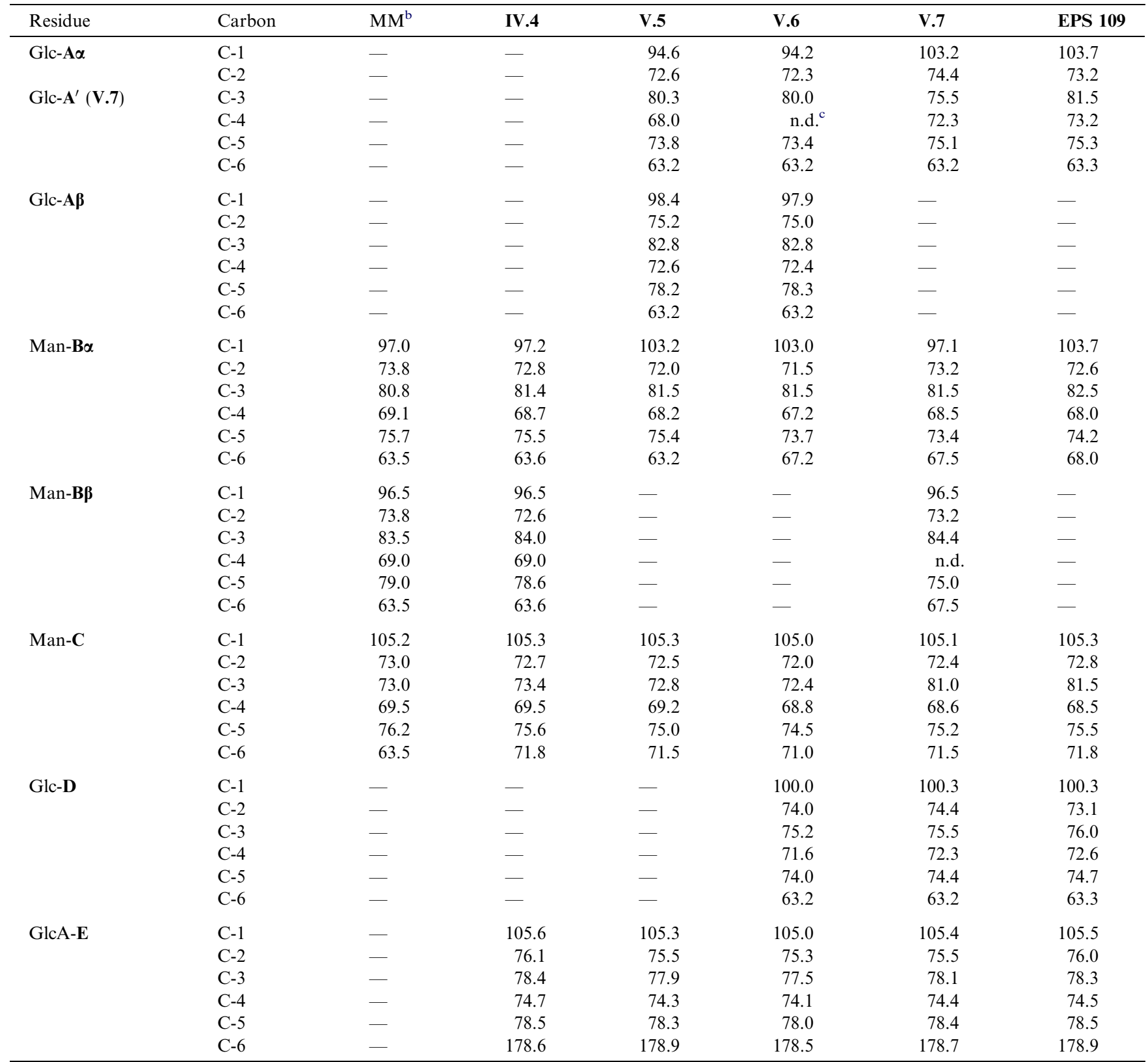

\footnotetext{
${ }^{\mathrm{a}}$ In ppm relative to the signal of internal acetone at $\delta 31.07$.

${ }^{\mathrm{b}}$ Reference compound: $\operatorname{Man}(\alpha 1-3)$ Man.

${ }^{\mathrm{c}}$ n.d., not determined.
}

3-substituted. In a similar way, the downfield chemical shifts of Man-B C-6 $\left(\delta_{\mathrm{C}-6} \quad 67.2 ; \alpha \operatorname{Man} p 1 \mathrm{Me}, \delta_{\mathrm{C}-6}\right.$ $\left.62.1^{18,19}\right)$ and Man-C C-6 $\left(\delta_{\mathrm{C}-6} 71.0 ; \alpha \operatorname{Man} p 1 \mathrm{Me}, \delta_{\mathrm{C}-6}\right.$ $62.1^{18,19}$ ) indicated these residues to be 6 -substituted.

The determination of the sequence of the monosaccharide residues within the pentasaccharide was established through the assignment of the inter-residue cross-peaks in the 2D ROESY spectrum (Fig. 4). On the ROESY E H-1 track, inter-residue cross-peaks with $\mathbf{C ~ H - 6 a , 6 b}$ were found, indicating an $\mathbf{E}(1 \rightarrow 6) \mathbf{C}$ linkage.
The ROESY cross-peak between $\mathbf{C}$ H-1 and $\mathbf{B}$ H-3 gave evidence for a $\mathbf{C}(1 \rightarrow 3) \mathbf{B}$ linkage. On the ROESY B H-1 track, inter-residue cross-peaks with $\mathbf{A} \boldsymbol{\alpha}$ and $\mathbf{A} \boldsymbol{\beta}$ H-3 were detected, supporting a $\mathbf{B}(1 \rightarrow 3) \mathbf{A}$ linkage. Furthermore, the inter-residue connectivity D H-1,B H-6a/6b proved the $\mathbf{D}(1 \rightarrow 6) \mathbf{B}$ linkage. The observed intraresidue ROESY cross-peaks were in accordance with the assigned anomeric configurations.

In conclusion, the structure of the pentasaccharide in fraction V.6 was established to be 

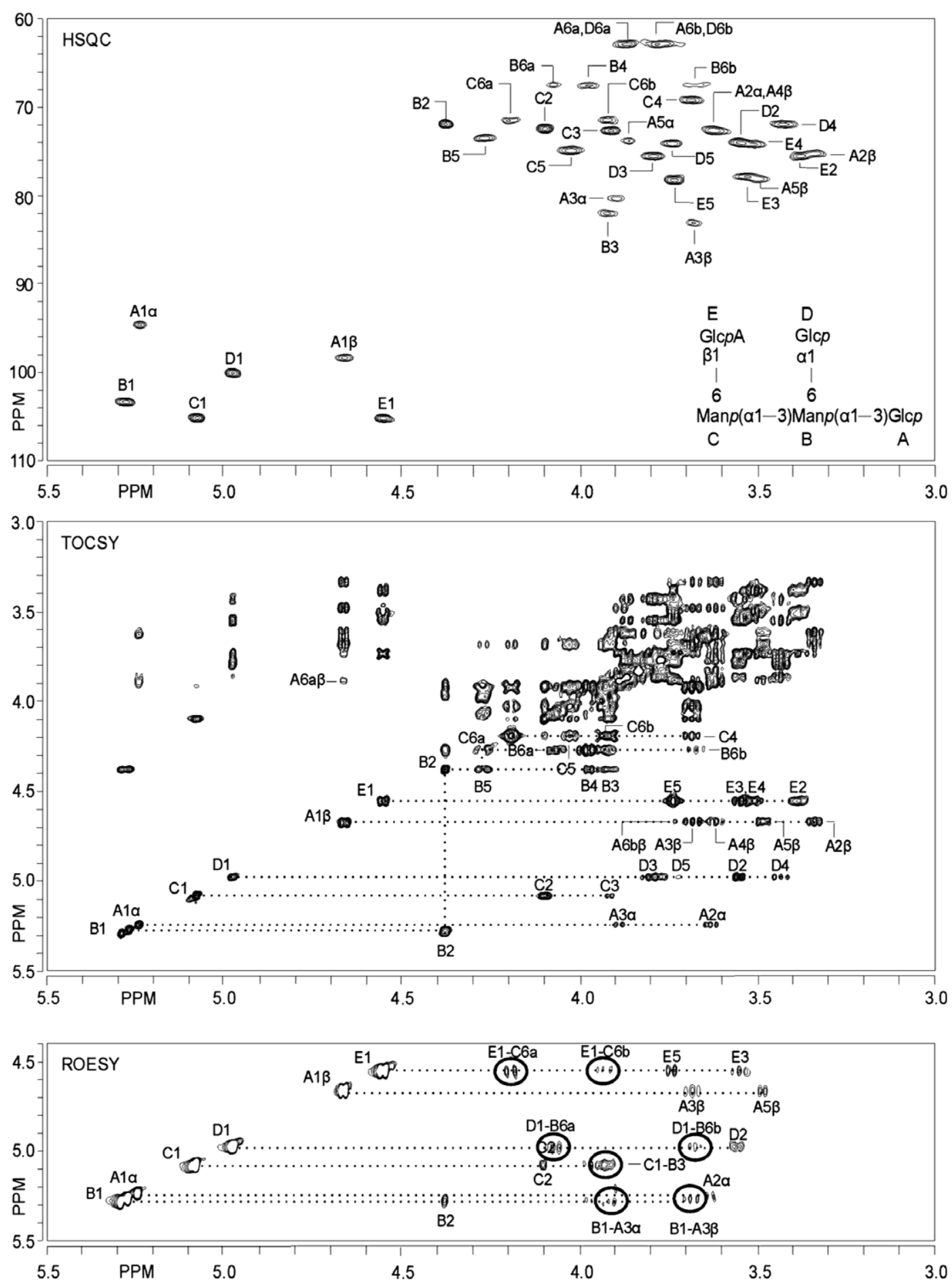

Figure 4. The HSQC spectrum, the TOCSY spectrum $(200 \mathrm{~ms})$ and the relevant part of the ROESY spectrum $(200 \mathrm{~ms})$ of V.6, recorded in $\mathrm{D}_{2} \mathrm{O}$ at $300 \mathrm{~K}$. The C-6 signal of GlcA was observed at $\delta_{\mathrm{C}} 178.5$ but is not included in the HSQC spectrum. Cross-peaks belonging to the same scalarcoupling network are indicated near a dotted line starting from the corresponding diagonal peaks; TOCSY: B1 corresponds to the diagonal peak of residue $\mathbf{B}$ H-1; B2 refers to a cross-peak between $\mathbf{B}$ H-1 and $\mathbf{B}$ H-2, etc.; ROESY: B1 corresponds to the diagonal peak of residue $\mathbf{B}$ H-1; B2 refers to an intra-residue cross-peak between $\mathbf{B}$ H-1 and $\mathbf{B}$ H-2, and B1-A $3 \alpha$ indicates an inter-residue connectivity between $\mathbf{B}$ H-1 and $\mathbf{A} \boldsymbol{\alpha}$ H-3, etc.; the crosspeaks confirming the glycosidic linkages are indicated with circles. The chemical structure of the pentasaccharide, including the annotation of the residues, is presented.

$\beta$-D-GlcpA-( $1 \rightarrow 6)-\alpha-\mathrm{D}-\mathrm{Man} p-(1 \rightarrow 3)-[\alpha-\mathrm{D}-\mathrm{Glc} p-(1 \rightarrow 6)-] \alpha-\mathrm{D}-\mathrm{Man} p-(1 \rightarrow 3)-\mathrm{D}-\mathrm{Glc} p$

$\mathbf{E}$

C

D
B

\section{A}


2.2.6. Fraction V.7. MALDI-TOFMS analysis of fraction V.7 showed a $[\mathrm{M}-\mathrm{H}+2 \mathrm{Na}]^{+}$pseudomolecular ion at $m / z$ 887.9, corresponding with HexAHex $_{4}$
$(M=842 \mathrm{Da})$. Monosaccharide analysis revealed the presence of GlcA, Man, and Glc in a molar ratio of $1: 2: 2$, whereas methylation analysis showed the presence
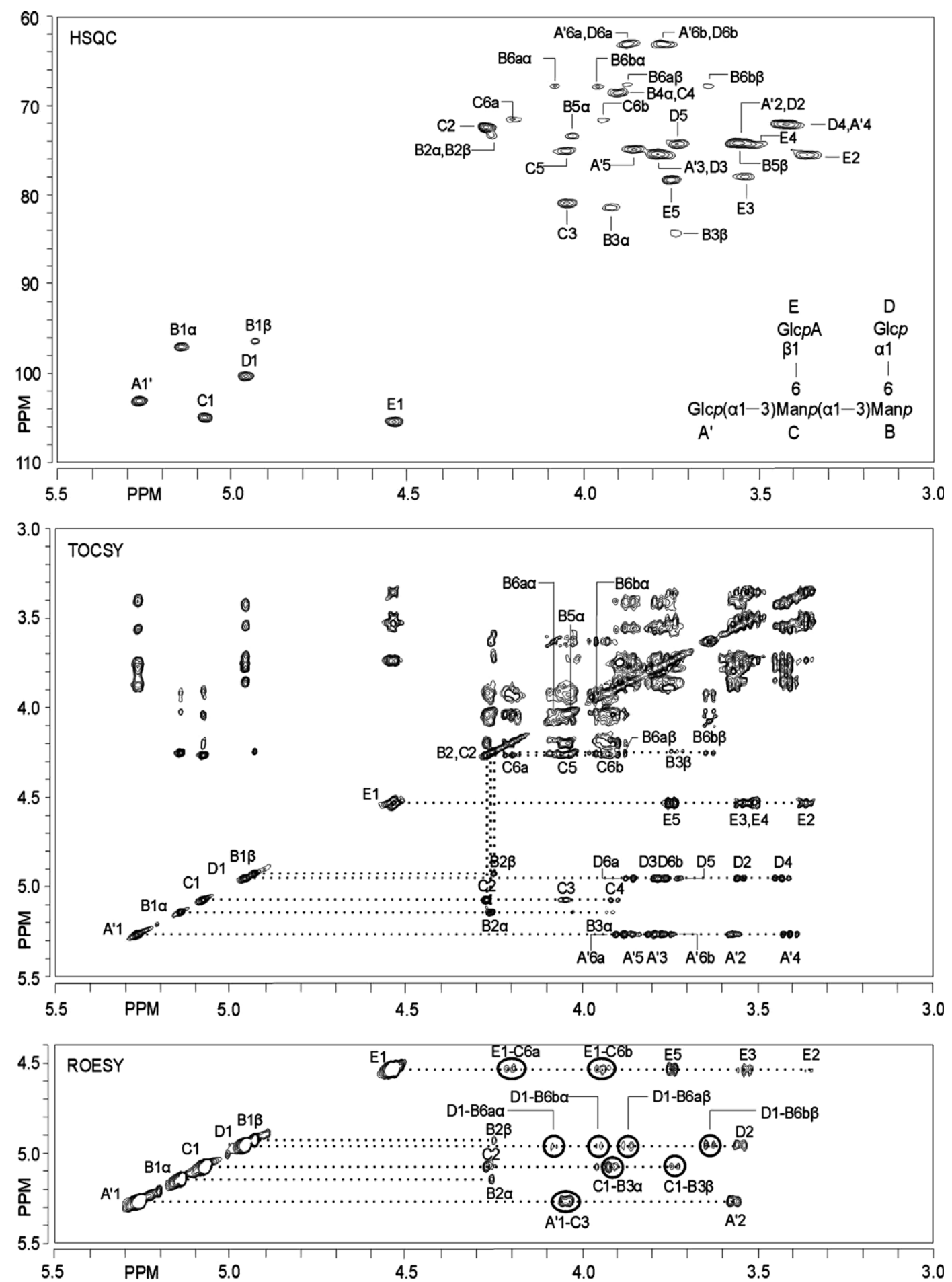

Figure 5. The HSQC spectrum, the TOCSY spectrum $(200 \mathrm{~ms})$ and the relevant part of the ROESY spectrum (200 ms) of V.7, recorded in $\mathrm{D}_{2} \mathrm{O}$ at $300 \mathrm{~K}$. The C-6 signal of GlcA was observed at $\delta_{\mathrm{C}} 178.7$ but is not included in the HSQC spectrum. Cross-peaks belonging to the same scalarcoupling network are indicated near a dotted line starting from the corresponding diagonal peaks; TOCSY: $\mathbf{A}^{\prime} 1$ corresponds to the diagonal peak of residue $\mathbf{A}^{\prime}$ H-1; $\mathbf{A}^{\prime} 2$ refers to a cross-peak between $\mathbf{A}^{\prime}$ H-1 and $\mathbf{A}^{\prime}$ H-2, etc.; ROESY: $\mathbf{A}^{\prime} 1$ corresponds to the diagonal peak of residue $\mathbf{A}^{\prime}$ H-1; $\mathbf{A}^{\prime} 2$ refers to an intra-residue cross-peak between $\mathbf{A}^{\prime} \mathrm{H}-1$ and $\mathbf{A}^{\prime}$ H-2, and $\mathbf{A}^{\prime} 1-\mathbf{C} 3$ indicates an inter-residue connectivity between $\mathbf{A}^{\prime} \mathrm{H}-1$ and $\mathbf{C}$ H-3, etc.; the cross-peaks confirming the glycosidic linkages are indicated with circles. The chemical structure of the pentasaccharide, including the annotation of the residues, is presented. 
of terminal Glc $p$ A, terminal Glc $p$, and 3,6-disubstituted Man $p$ (Table 2). Taking together these data, a branched pentasaccharide is indicated.

The 1D ${ }^{1} \mathrm{H}$ NMR spectrum of fraction V.7 (Fig. 3f) showed six anomeric signals, correlated with residues $\mathbf{A}_{\alpha / \boldsymbol{\beta}}^{\prime}, \mathbf{B} \boldsymbol{\alpha}, \mathbf{C}, \mathbf{D}_{\alpha / \boldsymbol{\beta}}, \mathbf{B} \boldsymbol{\beta}$, and $\mathbf{E}_{\boldsymbol{\alpha} / \boldsymbol{\beta}}$. The assignments of all
$\mathbf{A}^{\prime}(1 \rightarrow 3) \mathbf{C}, \mathbf{C}(1 \rightarrow 3) \mathbf{B}$, and $\mathbf{D}(1 \rightarrow 6) \mathbf{B}$ linkages, respectively. The observed intra-residue ROESY cross-peaks were in agreement with the assigned anomeric configurations.

In summary, it can be concluded that the structure of the branched pentasaccharide in fraction V.7 is

$$
\begin{array}{ccccc}
\beta-\mathrm{D}-\mathrm{Glc} p \mathrm{~A}-(1 \rightarrow 6)-[\alpha-\mathrm{D}-\mathrm{Glc} p-(1 \rightarrow 3)-] \alpha-\mathrm{D}-\mathrm{Man} p-(1 \rightarrow 3)-[\alpha-\mathrm{D}-\mathrm{Glc} p-(1 \rightarrow 6)-] \mathrm{D}-\mathrm{Man} p \\
\mathbf{E} & \mathbf{A}^{\prime} & \mathbf{C} & \mathbf{D} & \text { B }
\end{array}
$$

${ }^{1} \mathrm{H}$ and ${ }^{13} \mathrm{C}$ resonances of $\mathbf{V . 7}$ were obtained from $2 \mathrm{D}$ TOCSY (mixing times built-up, 40-200 ms) and 2D ${ }^{13} \mathrm{C}-{ }^{1} \mathrm{H}$ HSQC experiments, and are presented in Tables 4 and 5 , respectively. The $\mathrm{H}-1$ signal at $\delta_{\mathrm{H}} 4.531 / 4.538$ $\left(\mathbf{E}_{\boldsymbol{\alpha} / \boldsymbol{\beta}},{ }^{3} J_{1,2} 7.3 \mathrm{~Hz}\right)$ stems from $\beta$ Glc $p \mathrm{~A}$, whereas the $\mathrm{H}-1$ signals at $\delta_{\mathrm{H}} 5.078(\mathbf{C})$ and $\delta_{\mathrm{H}} 4.952 / 4.958\left(\mathbf{D}_{\alpha / \boldsymbol{\beta}}\right.$, ${ }^{3} J_{1,2} \sim 3.7 \mathrm{~Hz}$ ) belong to $\alpha \mathrm{Man} p$ and $\alpha \mathrm{Glc} p$, respectively (compare with the corresponding $\mathrm{H}-1$ signals of V.6). The two H-1 signals at $\delta_{\mathrm{H}} 5.143(\mathbf{B} \boldsymbol{\alpha})$ and $\delta_{\mathrm{H}} 4.925$ (Bß) are stemming from a reducing-end $\operatorname{Man} p$ residue, and the H-1 signal at $\delta_{\mathrm{H}} 5.262 / 5.275\left(\mathbf{A}_{\alpha / \boldsymbol{\beta}}^{\prime},{ }^{3} J_{1,2} \sim\right.$ $3.7 \mathrm{~Hz}$ ) from a non-reducing $\alpha-\mathrm{Glc} p$ residue.

In the TOCSY spectrum (200 ms, Fig. 5), the H-1 track of GlcA-E shows a complete spin system H-1,2,3,4,5, and the H-1 tracks of Glc-D and Glc- $\mathbf{A}^{\prime}$ complete spin systems $\mathrm{H}-1,2,3,4,5,6 \mathrm{a}, 6 \mathrm{~b}$. The Man-C $\mathrm{H}-1$ track allowed the observation of cross-peaks with $\mathbf{C ~ H - 2 , 3 , 4 , ~ w h e r e a s ~ t h e ~ c r o s s - p e a k s ~ f o r ~} \mathbf{C ~ H - 5 , 6 a , 6 b ~ w e r e ~}$ detected on the Man-C H-2 track. On the Man-B $\alpha$ H-1 track cross-peaks with $\mathbf{B} \boldsymbol{\alpha} \mathrm{H}-2$ and $\mathrm{H}-3$ were observed; the remaining signals were found via the $\mathbf{B}$ H-2 track, in combination with HSQC data. Finally, on the ManB $\boldsymbol{\beta}$ H-1 track a cross-peak with B $\boldsymbol{\beta}$ H-2 was found, and via the $\mathbf{B}$ H-2 track, in combination with HSQC data, the remaining signals were identified.

The HSQC spectrum (Fig. 5), containing the substitution information for the various residues, showed downfield shifts for Man-B C-3 $\left[\delta_{\mathrm{C}-3} 81.5(\alpha) / 84.4(\beta)\right.$; Man $p$, $\left.\delta_{\mathrm{C}-3} 71.3(\alpha) / 74.1(\beta)^{18,19}\right]$, Man-B C-6 [ $\delta_{\mathrm{C}-6} 67.5 ; \operatorname{Man} p$, $\left.\delta_{\mathrm{C}-6} 62.1^{18,19}\right]$, Man-C C-3 $\left(\delta_{\mathrm{C}-3} 81.0 ; \alpha \operatorname{Man} p 1 \mathrm{Me}, \delta_{\mathrm{C}-3}\right.$ $\left.71.8^{18,19}\right)$, and Man-C C-6 $\left(\delta_{\mathrm{C}-6} 71.5\right.$; $\alpha \operatorname{Man} p 1 \mathrm{Me}, \delta_{\mathrm{C}-6}$
2.2.7. Fraction V.a. MALDI-TOFMS analysis of fraction V.a showed a $[\mathrm{M}-\mathrm{H}+2 \mathrm{Na}]^{+}$pseudomolecular ion at $\mathrm{m} / z$ 728.1, corresponding to HexAHex ${ }_{2} \mathrm{Hex}-\mathrm{ol}$ $(M=682 \mathrm{Da})$. Monosaccharide analysis revealed the occurrence of GlcA, Glc, Man, and Man-ol in the molar ratio of $1: 1: 1: 1$, and methylation analysis revealed the presence of terminal Glc $p$ A, terminal Glc $p$, 6-substituted Manp, and 3,6-disubstituted Man-ol (Table 2), indicating a branched tetrasaccharide-alditol.

The $1 \mathrm{D}{ }^{1} \mathrm{H}$ NMR spectrum of fraction $\mathbf{V} . \mathbf{a}$ is depicted in Figure $3 \mathrm{~g}$. The assignments of the ${ }^{1} \mathrm{H}$ and ${ }^{13} \mathrm{C}$ chemical shifts of the constituent monomers of V.a were performed by means of 2D TOCSY (mixing times built-up, 40-200 ms) and 2D ${ }^{13} \mathrm{C}-{ }^{1} \mathrm{H}$ HSQC experiments (spectra not shown), and are presented in Tables 6 and 7, respectively. For comparison, the ${ }^{1} \mathrm{H}$ and ${ }^{13} \mathrm{C}$ data of Man(al-3)Man-ol have been included. The substitution patterns of GlcA-E, Man-C, Glc-D, and Man-B-ol followed directly from the ${ }^{13} \mathrm{C}$ data obtained from the HSQC measurements. Downfield shifts were observed for Man-C C-6 ( $\left.\delta_{\mathrm{C}-6} 72.0 ; \alpha \operatorname{Man} p 1 \mathrm{Me}, \delta_{\mathrm{C}-6} \quad 62.1^{18,19}\right)$, Man-B-ol C-3 ( $\delta_{\mathrm{C}-3}$ 82.3; Man-ol, $\left.\delta_{\mathrm{C}-3} 70.7^{21,22}\right)$, and Man-B-ol C-6 $\left(\delta_{\mathrm{C}-6} 72.2\right.$, Man-ol, $\left.\delta_{\mathrm{C}-6} 64.6^{21,22}\right)$. Furthermore, the inter-residue ROESY connectivities GlcA-E H-1,Man-C H-6a/6b, Man-C H-1,Man-B-ol H-2,3, and Glc-D H-1,Man-B-ol H-6a/6b demonstrated the presence of $\mathbf{E}(1 \rightarrow 6) \mathbf{C}, \mathbf{C}(1 \rightarrow 3) \mathbf{B}$-ol (taking into account the methylation analysis data), and $\mathbf{D}(1 \rightarrow 6)$ B-ol linkages.

Combining all data, fraction $\mathbf{V}$ a showed to contain the following branched tetrasaccharide-alditol:

$$
\begin{array}{cccc}
\beta-\mathrm{D}-\mathrm{Glc} p \mathrm{~A}-(1 \rightarrow 6)-\alpha-\mathrm{D}-\mathrm{Man} p-(1 \rightarrow 3)-[\alpha-\mathrm{D}-\mathrm{Glc} p-(1 \rightarrow 6)-] \text { Man-ol } \\
\mathbf{E} & \mathbf{C} & \mathbf{D} & \mathbf{B}-\mathrm{ol}
\end{array}
$$

$62.1^{18,19}$ ), indicating the involvement of these carbons in glycosidic linkages. The C-6 values of both terminal Glc residues ( $\mathbf{A}^{\prime}$ and $\left.\mathbf{D}\right)$ overlap at $\delta_{\mathrm{c}} 63.2$.

In the 2D ROESY spectrum (Fig. 5), the inter-residue connectivities GlcA-E H-1,Man-C H-6a/6b, Glc-A ${ }^{\prime}$ H-1,Man-C H-3, Man-C H-1,Man-B H-3, and Glc-D H-1,Man-B H-6a/6b are in accordance with $\mathbf{E}(1 \rightarrow 6) \mathbf{C}$,
2.2.8. Fraction V.b. MALDI-TOFMS analysis of fraction V.b revealed a $[\mathrm{M}-\mathrm{H}+2 \mathrm{Na}]^{+}$pseudomolecular ion at $m / z$ 890.1, in agreement with HexAHex ${ }_{3} \mathrm{Hex}$-ol $(M=844 \mathrm{Da})$. Monosaccharide analysis showed the presence of GlcA, Glc, Man, and Glc-ol in the molar ratio of 1:1:2:1, and methylation analysis showed the occurrence of terminal GlcpA, terminal Glcp, 6-substi- 
Table 6. ${ }^{1} \mathrm{H}$ NMR chemical shifts ${ }^{\mathrm{a}}$ of oligosaccharide-alditols obtained from a partial acid hydrolysate of EPS 109, recorded in $\mathrm{D}_{2} \mathrm{O}$ at $300 \mathrm{~K}$

\begin{tabular}{|c|c|c|c|c|c|}
\hline Residue & Proton & $\mathrm{MM}^{-\mathrm{ol}^{\mathrm{b}}}$ & V.a & V.b & V.c \\
\hline \multirow[t]{7}{*}{ Glc-A' } & H-1 & - & - & - & 5.264 \\
\hline & $\mathrm{H}-2$ & - & - & - & 3.56 \\
\hline & $\mathrm{H}-3$ & - & - & - & 3.78 \\
\hline & $\mathrm{H}-4$ & - & - & - & 3.40 \\
\hline & H-5 & - & - & - & 3.85 \\
\hline & H-6a & - & - & - & 3.87 \\
\hline & $\mathrm{H}-6 \mathrm{~b}$ & - & - & - & 3.76 \\
\hline \multirow[t]{7}{*}{ Man-B } & $\mathrm{H}-1$ & - & - & 5.032 & 5.035 \\
\hline & $\mathrm{H}-2$ & - & - & 4.22 & 4.22 \\
\hline & $\mathrm{H}-3$ & - & - & 3.94 & 3.94 \\
\hline & $\mathrm{H}-4$ & - & - & 3.94 & 3.94 \\
\hline & H-5 & - & - & 4.05 & 4.05 \\
\hline & H-6a & - & - & 4.06 & 4.05 \\
\hline & H-6b & - & - & 3.70 & 3.71 \\
\hline \multirow[t]{7}{*}{ Man-C } & $\mathrm{H}-1$ & 5.040 & 5.036 & 5.100 & 5.085 \\
\hline & $\mathrm{H}-2$ & 4.04 & 4.06 & 4.09 & 4.26 \\
\hline & $\mathrm{H}-3$ & 3.88 & 3.89 & 3.92 & 4.04 \\
\hline & $\mathrm{H}-4$ & 3.69 & 3.76 & 3.77 & 3.99 \\
\hline & H-5 & 3.80 & 3.99 & 3.96 & 3.96 \\
\hline & H-6a & 3.88 & 4.21 & 4.18 & 4.18 \\
\hline & H-6b & 3.78 & 3.90 & 3.94 & 3.94 \\
\hline \multirow[t]{7}{*}{ Glc-D } & $\mathrm{H}-1$ & - & 4.961 & 4.962 & 4.963 \\
\hline & $\mathrm{H}-2$ & - & 3.56 & 3.55 & 3.56 \\
\hline & $\mathrm{H}-3$ & - & 3.77 & 3.78 & 3.78 \\
\hline & $\mathrm{H}-4$ & - & 3.43 & 3.43 & 3.43 \\
\hline & H-5 & - & 3.75 & 3.75 & 3.75 \\
\hline & H-6a & - & 3.87 & 3.87 & 3.87 \\
\hline & H-6b & - & 3.76 & 3.76 & 3.76 \\
\hline \multirow[t]{5}{*}{ GlcA-E } & H-1 & - & 4.521 & 4.517 & 4.518 \\
\hline & $\mathrm{H}-2$ & - & 3.38 & 3.37 & 3.37 \\
\hline & $\mathrm{H}-3$ & - & 3.53 & 3.53 & 3.53 \\
\hline & $\mathrm{H}-4$ & - & 3.53 & 3.53 & 3.53 \\
\hline & H-5 & - & 3.75 & 3.74 & 3.75 \\
\hline \multirow[t]{8}{*}{ Glc-ol-A } & $\mathrm{H}-1 \mathrm{a}$ & - & - & 3.83 & 3.83 \\
\hline & $\mathrm{H}-1 \mathrm{~b}$ & - & - & 3.69 & 3.69 \\
\hline & $\mathrm{H}-2$ & - & - & 3.99 & 3.99 \\
\hline & $\mathrm{H}-3$ & - & - & 4.00 & 4.00 \\
\hline & $\mathrm{H}-4$ & - & - & 3.77 & 3.77 \\
\hline & H-5 & - & - & 3.66 & 3.66 \\
\hline & H-6a & - & - & 3.83 & 3.83 \\
\hline & H-6b & - & - & 3.68 & 3.69 \\
\hline \multirow[t]{8}{*}{ Man-ol-B } & H-1a & 3.85 & 3.86 & - & - \\
\hline & $\mathrm{H}-1 \mathrm{~b}$ & 3.67 & 3.68 & - & - \\
\hline & $\mathrm{H}-2$ & 3.95 & 3.95 & - & - \\
\hline & $\mathrm{H}-3$ & 4.01 & 4.03 & - & - \\
\hline & $\mathrm{H}-4$ & 3.85 & 3.82 & - & - \\
\hline & H-5 & 3.64 & n.d. ${ }^{\mathrm{c}}$ & - & - \\
\hline & H-6a & 3.85 & 3.94 & - & - \\
\hline & H-6b & 3.67 & 3.71 & - & - \\
\hline
\end{tabular}

${ }^{\mathrm{a}}$ In ppm relative to the signal of internal acetone at $\delta 2.225$.

${ }^{\mathrm{b}}$ Reference compound: Man( $\left.\alpha 1-3\right)$ Man-ol.

${ }^{\mathrm{c}}$ n.d., not determined.

tuted Manp, 3,6-disubstituted Manp, and 3-substituted Glc-ol (Table 2), indicating a branched pentasaccharide-alditol.
Table $7 .{ }^{13} \mathrm{C}$ NMR chemical shifts ${ }^{\mathrm{a}}$ of oligosaccharide-alditols obtained from a partial acid hydrolysate of EPS 109, recorded in $\mathrm{D}_{2} \mathrm{O}$ at $300 \mathrm{~K}$

\begin{tabular}{|c|c|c|c|c|c|}
\hline Residue & Carbon & MM-ol $^{\mathrm{b}}$ & V.a & V.b & V.c \\
\hline \multirow[t]{6}{*}{ Glc-A' } & $\mathrm{C}-1$ & - & - & - & 103.9 \\
\hline & C-2 & - & - & - & 75.2 \\
\hline & C-3 & - & - & - & 76.3 \\
\hline & C-4 & - & - & - & 73.2 \\
\hline & C-5 & - & - & - & 75.6 \\
\hline & C-6 & - & - & - & 64.1 \\
\hline \multirow[t]{6}{*}{ Man-B } & $\mathrm{C}-1$ & - & - & 105.6 & 105.7 \\
\hline & $\mathrm{C}-2$ & - & - & 73.0 & 73.0 \\
\hline & $\mathrm{C}-3$ & - & - & 82.8 & 82.8 \\
\hline & C-4 & - & - & 68.8 & 68.8 \\
\hline & C-5 & - & - & 75.3 & 75.4 \\
\hline & C-6 & - & - & 69.0 & 69.1 \\
\hline \multirow[t]{6}{*}{ Man-C } & $\mathrm{C}-1$ & 105.8 & 106.0 & 106.0 & 106.0 \\
\hline & $\mathrm{C}-2$ & 73.6 & 73.5 & 73.5 & 73.2 \\
\hline & C-3 & 73.6 & 73.5 & 73.5 & 81.6 \\
\hline & C- 4 & 70.2 & 69.9 & 69.9 & 69.0 \\
\hline & C-5 & 77.0 & 75.6 & 75.7 & 75.8 \\
\hline & C-6 & 63.9 & 72.0 & 72.1 & 72.0 \\
\hline \multirow[t]{6}{*}{ Glc-D } & $\mathrm{C}-1$ & - & 101.5 & 101.3 & 101.3 \\
\hline & $\mathrm{C}-2$ & - & 75.0 & 75.0 & 75.2 \\
\hline & C-3 & - & 76.5 & 76.4 & 76.3 \\
\hline & C-4 & - & 73.3 & 73.1 & 73.2 \\
\hline & $\mathrm{C}-5$ & - & 75.3 & 75.1 & 75.3 \\
\hline & C-6 & - & 63.9 & 63.8 & 64.1 \\
\hline \multirow[t]{6}{*}{ GlcA-E } & $\mathrm{C}-1$ & - & 106.1 & 106.0 & 106.2 \\
\hline & C-2 & - & 76.3 & 76.2 & 76.3 \\
\hline & C-3 & - & 78.9 & 78.9 & 78.8 \\
\hline & C-4 & - & 75.3 & 75.1 & 75.2 \\
\hline & C-5 & - & 79.3 & 79.3 & 79.2 \\
\hline & C-6 & - & 178.3 & 178.1 & 178.2 \\
\hline \multirow[t]{6}{*}{ Glc-ol-A } & C-1 & - & - & 65.5 & 65.8 \\
\hline & C-2 & - & - & 75.8 & 75.6 \\
\hline & C-3 & - & - & 82.8 & 82.8 \\
\hline & C-4 & - & - & 73.1 & 73.0 \\
\hline & $\mathrm{C}-5$ & - & - & 74.4 & 74.5 \\
\hline & C-6 & - & - & 66.2 & 66.1 \\
\hline \multirow[t]{6}{*}{ Man-ol-B } & C-1 & 66.5 & 66.1 & - & - \\
\hline & $\mathrm{C}-2$ & 75.8 & 73.5 & - & - \\
\hline & $\mathrm{C}-3$ & 82.0 & 82.3 & - & - \\
\hline & C-4 & 73.4 & 72.8 & - & - \\
\hline & C-5 & 74.3 & n.d. ${ }^{\mathrm{c}}$ & - & - \\
\hline & C-6 & 66.5 & 72.2 & - & - \\
\hline
\end{tabular}

${ }^{\mathrm{a}}$ In ppm relative to the signal of internal acetone at $\delta 31.07$.

${ }^{\mathrm{b}}$ Reference compound: Man( $\left.\alpha 1-3\right)$ Man-ol.

${ }^{\mathrm{c}}$ n.d., not determined.

The 1D ${ }^{1} \mathrm{H}$ NMR spectrum of fraction V.b is presented in Figure $3 \mathrm{~h}$. The assignments of all ${ }^{1} \mathrm{H}$ and ${ }^{13} \mathrm{C}$ resonances were obtained from $2 \mathrm{D}$ TOCSY (mixing times built-up, 40-200 ms) and $2 \mathrm{D}{ }^{13} \mathrm{C}-{ }^{1} \mathrm{H}$ HSQC experiments (spectra not shown), and are presented in Tables 6 and 7, respectively. To confirm the $\alpha$-anomeric configurations for Man-B and Man-C, ${ }^{1} J_{\mathrm{C}-1, \mathrm{H}-1}$ values were measured via $2 \mathrm{D}{ }^{13} \mathrm{C}-{ }^{1} \mathrm{H}$ HMBC experiments, and turned out to be $171.5 \mathrm{~Hz}$ in both cases; Glc-D 
showed a ${ }^{1} J_{\mathrm{C}-1, \mathrm{H}-1}$ value of $170.0 \mathrm{~Hz}$, supporting the $\alpha$ configuration, and GlcA-E a ${ }^{1} J_{\mathrm{C}-1, \mathrm{H}-1}$ value of 154.0 Hz, supporting the $\beta$ configuration. The substitu- tion patterns of GlcA-E, Man-C, Glc-D, Man-B, and Glc-A-ol followed directly from the ${ }^{13} \mathrm{C}$ data obtained from the HSQC measurements. Downfield shifts were
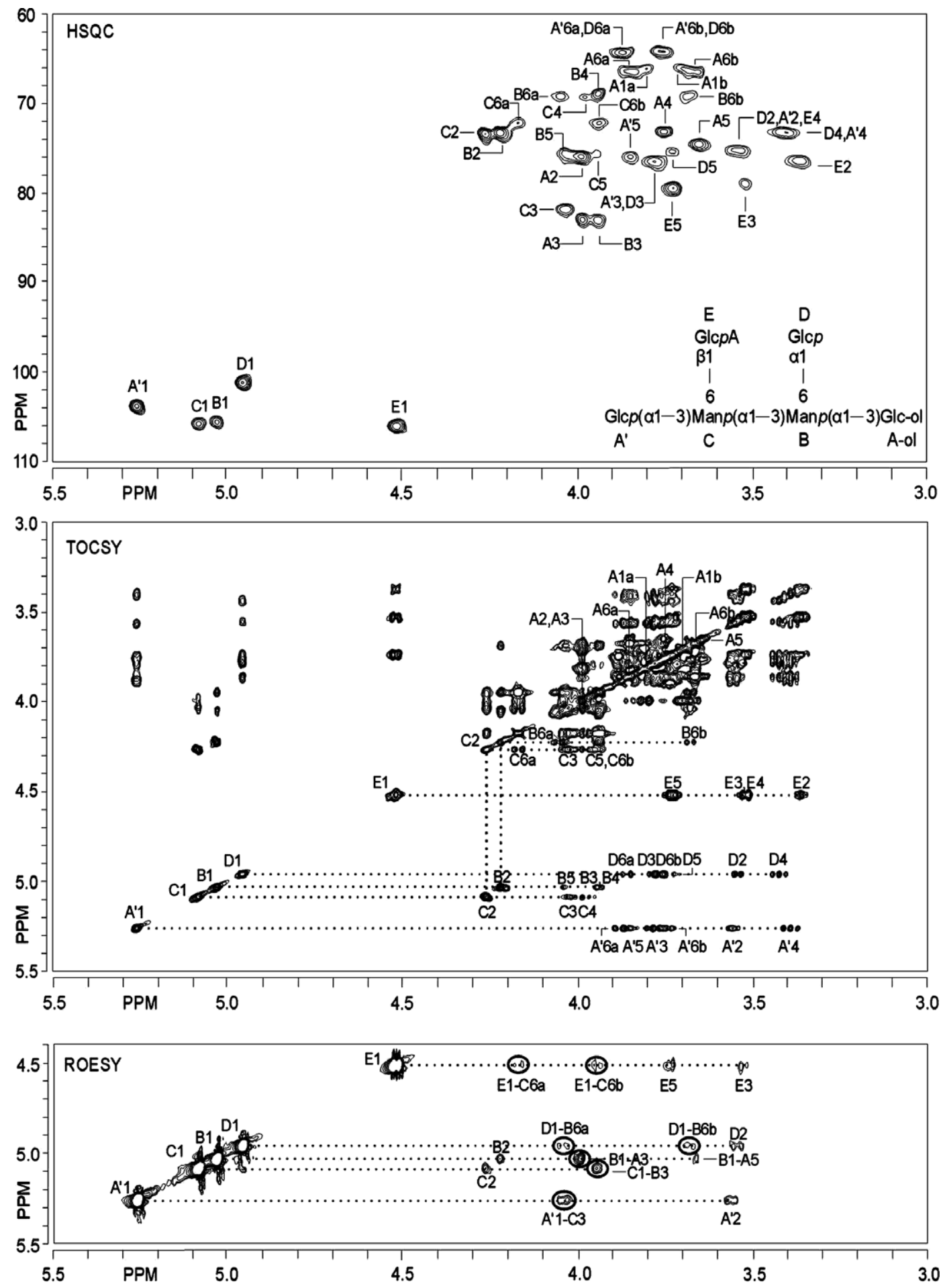

Figure 6. The HSQC spectrum, the TOCSY spectrum $(200 \mathrm{~ms})$ and the relevant part of the ROESY spectrum $(200 \mathrm{~ms})$ of V.c, recorded in $\mathrm{D}_{2} \mathrm{O}$ at $300 \mathrm{~K}$. The C-6 signal of GlcA was observed at $\delta_{\mathrm{C}} 178.2$ but is not included in the HSQC spectrum. Cross-peaks belonging to the same scalarcoupling network are indicated near a dotted line starting from the corresponding diagonal peaks; TOCSY: D1 corresponds to the diagonal peak of residue D H-1; D2 refers to a cross-peak between D H-1 and D H-2, etc.; ROESY: D1 corresponds to the diagonal peak of residue D H-1; D2 refers to an intra-residue cross-peak between $\mathbf{D} \mathrm{H}-1$ and $\mathbf{D}$ H-2, and D1-B6a indicates an inter-residue connectivity between $\mathbf{D}$ H-1 and $\mathbf{B}$ H-6a, etc.; the cross-peaks confirming the glycosidic linkages are indicated with circles. The chemical structure of the hexasaccharide-alditol, including the annotation of the residues, is presented. 
observed for Man-C C-6 $\left(\delta_{\mathrm{C}-6} 72.1 ; \alpha \operatorname{Man} p 1 \mathrm{Me}, \delta_{\mathrm{C}-6}\right.$ $\left.62.1^{18,19}\right)$, Man-B C-3 $\left(\delta_{\mathrm{C}-3} \quad 82.8 ; \alpha \operatorname{Man} p 1 \mathrm{Me}, \delta_{\mathrm{C}-3}\right.$ $\left.71.8^{18,19}\right)$, Man-B C-6 $\left(\delta_{\mathrm{C}-6} 69.0, \alpha \operatorname{Man} p 1 \mathrm{Me}, \delta_{\mathrm{C}-6}\right.$ $\left.62.1^{18,19}\right)$, and Glc-A-ol C-3 $\left(\delta_{\mathrm{C}-3} 82.8\right.$; Glc-ol, $\delta_{\mathrm{C}-3}$ $\left.71.0^{22,23}\right)$. Furthermore, the inter-residue ROESY connectivities GlcA-E H-1,Man-C H-6a/6b, Man-C H-1, Man-B H-3, Glc-D H-1,Man-B H-6a/6b, and Man-B H-1,Glc-A-ol H-3 demonstrated the presence of
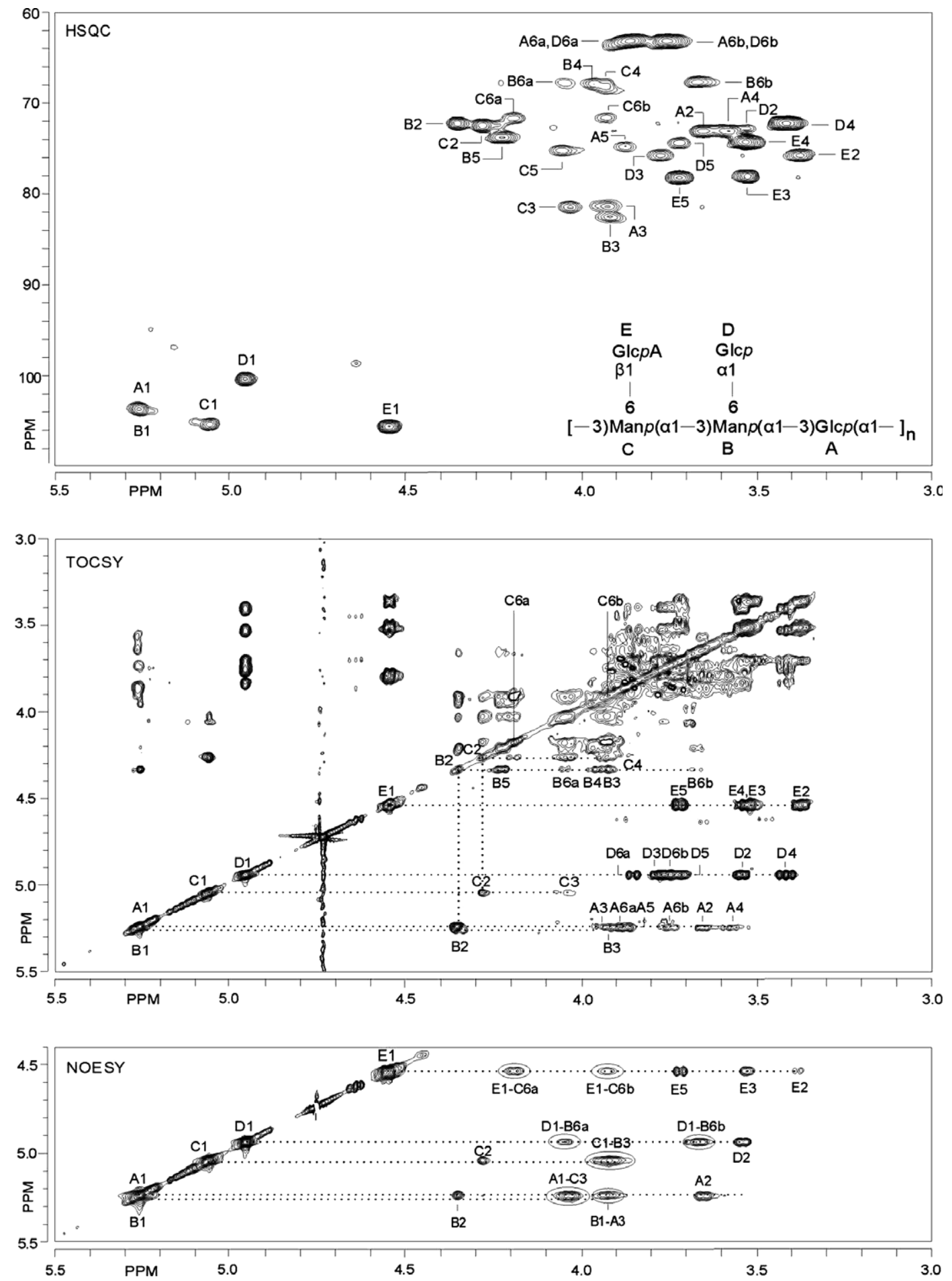

Figure 7. The HSQC spectrum (200 ms), the TOCSY spectrum $(200 \mathrm{~ms})$ and the relevant part of the NOESY spectrum ( $50 \mathrm{~ms})$ of EPS 109, recorded in $\mathrm{D}_{2} \mathrm{O}$ at $300 \mathrm{~K}$. The C-6 signal of GlcA was observed at $\delta_{\mathrm{C}} 178.9$ but is not included in the HSQC spectrum. Cross-peaks belonging to the same scalar-coupling network are indicated near a dotted line starting from the corresponding diagonal peaks; TOCSY: E1 corresponds to the diagonal peak of residue $\mathbf{E}$ H-1; E2 refers to a cross-peak between $\mathbf{E}$ H-1 and $\mathbf{E}$ H-2, etc.; NOESY: E1 corresponds to the diagonal peak of residue $\mathbf{E}$ H-1; E2 refers to an intra-residue cross-peak between $\mathbf{E}$ H-1 and $\mathbf{E}$ H-2, and E1-C6a indicates an inter-residue connectivity between $\mathbf{E}$ H-1 and $\mathbf{C}$ H-6a, etc.; the cross-peaks confirming the glycosidic linkages are indicated with circles. 
$\mathbf{E}(1 \rightarrow 6) \mathbf{C}, \quad \mathbf{C}(1 \rightarrow 3) \mathbf{B}, \quad \mathbf{D}(1 \rightarrow 6) \mathbf{B}, \quad$ and $\quad \mathbf{B}(1 \rightarrow 3) \mathbf{A}-\mathrm{ol}$ linkages.

Taking together all information, fraction V.b was shown to contain the following compound: downfield chemical shifts of Man-B C-3 $\left(\delta_{\mathrm{C}-3} 82.8\right.$, $\left.\alpha \operatorname{Man} p 1 \mathrm{Me}, \quad \delta_{\mathrm{C}-3} \quad 71.8^{18,19}\right)$ and $\mathrm{C}-6 \quad\left(\delta_{\mathrm{C}-6} 69.1\right.$, $\left.\alpha \operatorname{Man} p 1 \mathrm{Me}, \delta_{\mathrm{C}-6} 62.1^{18,19}\right)$, and Man-C C-3 $\left(\delta_{\mathrm{C}-3} 81.6\right)$ and C-6 $\left(\delta_{\mathrm{C}-6} 72.0\right)$ demonstrate that both Man residues

$$
\begin{array}{ccccc}
\beta-\mathrm{D}-\mathrm{GlcpA}-(1 \rightarrow 6)-\alpha-\mathrm{D}-\mathrm{Man} p-(1 \rightarrow 3)-[\alpha-\mathrm{D}-\mathrm{Glc} p-(1 \rightarrow 6)-] \alpha-\mathrm{D}-\mathrm{Man} p-(1 \rightarrow 3)-\mathrm{Glc}-\mathrm{ol} \\
\mathbf{E} & \mathbf{C} & \mathbf{D} & \mathbf{B} & \mathbf{A}-\mathrm{ol}
\end{array}
$$

2.2.9. Fraction V.c. MALDI-TOFMS analysis of fraction V.c showed a $[\mathrm{M}-\mathrm{H}+2 \mathrm{Na}]^{+}$pseudomolecular ion at $m / z$ 1052.0, corresponding to $\mathrm{HexAHex}_{4} \mathrm{Hex}$-ol $(M=1006 \mathrm{Da})$. Monosaccharide analysis showed the occurrence of GlcA, Glc, Man, and Glc-ol in the molar ratio of 1:2:2:1, and methylation analysis showed the presence of terminal Glc $p \mathrm{~A}$, terminal Glc $p$, 3,6-disubstituted Manp, and 3-substituted Glc-ol (Table 2), supporting a branched hexasaccharide-alditol.

The $1 \mathrm{D}{ }^{1} \mathrm{H}$ NMR spectrum showed five anomeric signals (Fig. 3i), correlated with the residues $\mathbf{A}^{\prime}, \mathbf{C}, \mathbf{B}, \mathbf{D}$, are 3,6-disubstituted; the resonance position of Glc-ol-A $\mathrm{C}-3\left(\delta_{\mathrm{C}-3} 82.8\right.$, Glc-ol, $\left.\delta_{\mathrm{C}-3} 71.0^{22,23}\right)$ reflects a 3 -substitution for Glc-ol-A.

The sequence of the residues was established through the assignment of the inter-residue cross-peaks $\mathbf{E}$ H-1, $\mathbf{C}$ H-6a/6b, A' H-1, C H-3, C H-1,B H-3, D H-1, B H-6a/6b, and $\mathbf{B} \mathrm{H}-1, \mathbf{A}-\mathbf{o l} \mathrm{H}-3$ in the 2D ROESY spectrum (Fig. 6), showing $\mathbf{E}(1 \rightarrow 6) \mathbf{C}, \quad \mathbf{A}^{\prime}(1 \rightarrow 3) \mathbf{C}, \quad \mathbf{C}(1 \rightarrow 3) \mathbf{B}$, $\mathbf{D}(1 \rightarrow 6) \mathbf{B}$, and $\mathbf{B}(1 \rightarrow 3) \mathbf{A}$-ol linkages.

Based on the various analytical data, the hexasaccharide-alditol in fraction V.c has the structure

\section{$\mathbf{E}$ \\ $\mathbf{A}^{\prime}$ \\ C \\ D \\ B \\ A-ol}

$\beta$-D-GlcpA-( $1 \rightarrow 6)-[\alpha-\mathrm{D}-\mathrm{Glc} p-(1 \rightarrow 3)-] \alpha-\mathrm{D}-\mathrm{Man} p-(1 \rightarrow 3)$-[ $\alpha$-D -Glcp-( $1 \rightarrow 6)-] \alpha-\mathrm{D}-\mathrm{Man} p-(1 \rightarrow 3)-\mathrm{Glc}-\mathrm{ol}$

and E. The assignments of the ${ }^{1} \mathrm{H}$ and ${ }^{13} \mathrm{C}$ resonances of V.c were obtained from 2D TOCSY (mixing times built-up, 40-200 ms) and $2 \mathrm{D}{ }^{13} \mathrm{C}-{ }^{1} \mathrm{H}$ HSQC experiments, and are surveyed in Tables 6 and 7, respectively. The TOCSY spectrum with a mixing time of $200 \mathrm{~ms}$ is depicted in Figure 6, together with the HSQC and the ROESY (mixing time, $200 \mathrm{~ms}$ ) spectra. The TOCSY E $\mathrm{H}-1$ track $\left(\delta_{\mathrm{H}} 4.518,{ }^{3} J_{1,2} 7.4 \mathrm{~Hz}\right)$ showed the complete spin system $\mathrm{H}-1,2,3,4,5$, typical for a $\beta$ Glc $p \mathrm{~A}$ residue. ${ }^{19,20}$ Both the $\mathbf{A}^{\prime} \mathrm{H}-1\left(\delta_{\mathrm{H}} 5.264,{ }^{3} J_{1,2} 3.7 \mathrm{~Hz}\right)$ and D H-1 $\left(\delta_{\mathrm{H}} 4.963,{ }^{3} J_{1,2} 3.7 \mathrm{~Hz}\right)$ tracks revealed complete $\mathrm{H}-1,2,3,4,5,6 \mathrm{a}, 6 \mathrm{~b}$ spin systems, which were identified as belonging to $\alpha$ Glc $p$ residues. On the B H-1 track $\left(\delta_{\mathrm{H}}\right.$ $\left.5.035,{ }^{3} J_{1,2}<2 \mathrm{~Hz}\right)$ cross-peaks with $\mathrm{H}-2,3,4,5$ are observed, and on the C H-1 track $\left(\delta_{\mathrm{H}} 5.085,{ }^{3} J_{1,2}\right.$ $<2 \mathrm{~Hz}$ ) cross-peaks with $\mathrm{H}-2,3,4$; in both cases the $\mathrm{H}-2$ values are indicative for Man $p$ residues, whereas the $\mathrm{C}-1$ values fit perfectly those of the $\alpha \mathrm{Man} p-\mathbf{B}$ and -C residues of compound $\mathbf{V} . \mathbf{b}$. The missing signals of $\mathbf{B}$ and $\mathbf{C}$ follow from inspection of the respective TOCSY H-2 tracks. The assignment of the ${ }^{1} \mathrm{H}$ signals of Glc-ol-A were deduced from the TOCSY spectra, making use of a reference spectrum of a 3 -substituted Glc-ol, ${ }^{23}$ both the ${ }^{1} \mathrm{H}$ and ${ }^{13} \mathrm{C}$ data were similar to those found for Glc-ol-A in V.b.

Taking into account the literature data of ${ }^{13} \mathrm{C}$ chemical shifts of methyl aldosides and alditols, ${ }^{18,19,22}$ the

\subsection{D NMR spectroscopy of EPS 109}

The complete assignments of the ${ }^{1} \mathrm{H}$ and ${ }^{13} \mathrm{C}$ chemical shifts of EPS 109 (Tables 4 and 5, respectively) were performed by means of 2D TOCSY (mixing times built-up, 40-200 ms) and $2 \mathrm{D}{ }^{13} \mathrm{C}-{ }^{1} \mathrm{H}$ HSQC experiments. For the sequence analysis of the monomers, 2D NOESY and 2D ${ }^{13} \mathrm{C}-{ }^{1} \mathrm{H}$ HMBC experiments were carried out. The HSQC, TOCSY (200 ms), and NOESY (50 ms) spectra are shown in Figure 7. Starting points for the interpretations of the different spectra were always the anomeric signals of the residues A-E. The interpretations of the 2D spectra were facilitated by the data already obtained for the oligosaccharides(-alditols), as described in Section 2.2. As stated already for the analysis of the fragments of EPS 109, comparison of TOCSY spectra with increasing mixing times allowed the assignment of the sequential order of the chemical shifts belonging to a single spin system.

On the TOCSY E $(\beta \mathrm{Glc} p \mathrm{~A}) \mathrm{H}-1$ track $\left(\delta_{\mathrm{H}} 4.541,{ }^{3} J_{1,2}\right.$ $8.5 \mathrm{~Hz}$ ), the complete series of cross-peaks with H-2,3,4,5 were observed. ${ }^{24}$ Also the TOCSY D $(\alpha \mathrm{Glc} p)$ $\mathrm{H}-1\left(\delta_{\mathrm{H}} 4.964,{ }^{3} J_{1,2}<4.0 \mathrm{~Hz}\right)$ and $\mathbf{A}(\alpha \mathrm{Glc} p) \mathrm{H}-1$ tracks $\left(\delta_{\mathrm{H}} 5.260,{ }^{3} J_{1,2}<4.0 \mathrm{~Hz}\right)$ showed the complete spin system H-2,3,4,5,6a,6b. The TOCSY B H-1 $\left(\delta_{\mathrm{H}} 5.260\right)$ and C H-1 tracks $\left(\delta_{\mathrm{H}} 5.056\right)$ are typical for $\alpha \mathrm{Man} p$ residues, showing intense cross-peaks with $\mathrm{H}-2$ and less intense 
Table 8. Significant ${ }^{3} J_{\mathrm{H}, \mathrm{C}}$ connectivities observed in the HMBC spectrum for the anomeric protons/carbons of the monosaccharide residues of EPS 109 from $P$. freudenreichii 109

\begin{tabular}{|c|c|c|c|c|c|}
\hline \multirow[t]{2}{*}{ Residue } & \multirow[t]{2}{*}{ Monosaccharide linkage } & \multirow{2}{*}{$\begin{array}{l}\mathrm{H}-1 / \mathrm{C}-1 \\
\delta_{\mathrm{H}} / \delta_{\mathrm{C}}\end{array}$} & \multicolumn{3}{|c|}{ Observed connectivities } \\
\hline & & & $\delta_{\mathrm{H}} / \delta_{\mathrm{C}}$ & Residue & Atom \\
\hline \multirow[t]{4}{*}{$\mathbf{A}$} & $\rightarrow 3)-\alpha-\mathrm{D}-\mathrm{Glc} p-(1 \rightarrow$ & 5.260 & 75.3 & $\mathbf{A}$ & C-5 \\
\hline & & & 81.5 & $\mathbf{C}^{*}$ & C-3 \\
\hline & & 103.7 & 4.04 & $\mathbf{C}^{*}$ & $\mathrm{H}-3$ \\
\hline & & & 3.93 & $\mathbf{A}$ & $\mathrm{H}-3$ \\
\hline \multirow[t]{4}{*}{$\mathbf{B}$} & $\rightarrow 3,6)-\alpha-\mathrm{D}-\operatorname{Man} p-(1 \rightarrow$ & 5.260 & 74.2 & $\mathbf{B}$ & C-5 \\
\hline & & & 82.5 & B & $\mathrm{C}-3$ \\
\hline & & & 81.5 & $\mathbf{A}^{*}$ & $\mathrm{C}-3$ \\
\hline & & 103.7 & 3.92 & B & $\mathrm{H}-3$ \\
\hline \multirow[t]{3}{*}{$\mathbf{C}$} & $\rightarrow 3,6)-\alpha-\mathrm{D}-\operatorname{Man} p-(1 \rightarrow$ & 5.056 & 75.5 & $\mathbf{C}$ & C-5 \\
\hline & & & 81.5 & $\mathbf{C}$ & C-3 \\
\hline & & & 82.5 & $\mathbf{B}^{*}$ & $\mathrm{C}-3$ \\
\hline \multirow{2}{*}{ D } & & & 76.0 & D & $\mathrm{C}-3$ \\
\hline & & & 68.0 & $\mathbf{B}^{*}$ & C-6 \\
\hline \multirow[t]{2}{*}{$\mathbf{E}$} & $\beta-\mathrm{D}-\mathrm{Glc} p \mathrm{~A}-(1 \rightarrow$ & 4.541 & 71.8 & $\mathrm{C}^{*}$ & C-6 \\
\hline & & 105.5 & 3.38 & $\mathbf{E}$ & $\mathrm{H}-2$ \\
\hline
\end{tabular}

Glycosidic linkages are indicated with ${ }^{*}$.

cross-peaks with $\mathrm{H}-3$. The assignments of the remaining $\mathrm{H}-4$ to $\mathrm{H}-6 \mathrm{a}, 6 \mathrm{~b}$ resonances of residues $\mathbf{B}$ and $\mathbf{C}$ were obtained via their $\mathrm{H}-2$ tracks, respectively.

Inspection of the ${ }^{13} \mathrm{C}$ chemical shifts (Table 5), obtained by interpretation of the $2 \mathrm{D}{ }^{13} \mathrm{C}-{ }^{1} \mathrm{H}$ HSQC spectrum (Fig. 7), thereby sometimes making use of the TOCSY data, yielded the substitution pattern of the constituent monosaccharides, confirming those seen in the fragments of EPS 109: terminal residues $\beta$ Glc $p$ A-E and $\alpha$ Glcp-D; 3- and 6-substituted $\alpha \operatorname{Man} p$ $\mathbf{C}\left(\delta_{\mathrm{C}-3} 81.5 ; \delta_{\mathrm{C}-6} 71.8\right), 3$ - and 6-substituted $\alpha \mathrm{Man} p-\mathbf{B}$ $\left(\delta_{\mathrm{C}-3} 82.5 ; \delta_{\mathrm{C}-6} 68.0\right)$, and 3 -substituted $\alpha \mathrm{Glc} p-\mathbf{A}\left(\delta_{\mathrm{C}-3}\right.$ 81.5, $\alpha$ Glc $\left.p 1 \mathrm{Me}, \delta_{\mathrm{C}-3} 74.1^{18,19}\right)$.

Inspection of the 2D NOESY spectrum (Fig. 7) showed on the $\mathbf{E}$ H-1 track an NOE connectivity with $\mathbf{C ~ H - 6 a}$ and $\mathrm{H}-6 \mathrm{~b}$, in agreement with the $\mathbf{E}(1 \rightarrow 6) \mathbf{C}$ linkage. The inter-residue NOE cross-peaks between $\mathbf{A}$ H-1 and $\mathbf{C}$ H-3 supported the $\mathbf{A}(1 \rightarrow 3) \mathbf{C}$ linkage, indicating the branching position of residue $\mathbf{C}$. In a similar reasoning, the branching position of residue $\mathbf{B}$ and its connection with residue $\mathbf{C}$ is indicated by the cross-peaks $\mathbf{D}$ H-1,B H-6a/6b on the D H-1 track and the cross-peaks C H-1,B H-3 on the C-1 track, in agreement with $\mathbf{D}(1 \rightarrow 6) \mathbf{B}$ and $\mathbf{C}(1 \rightarrow 3) \mathbf{B}$ linkages, respectively. Furthermore, the observed NOE cross-peak between $\mathbf{B} \mathrm{H}-1$ and A $\mathrm{H}-3$ supported the remaining $\mathbf{B}(1 \rightarrow 3) \mathbf{A}$ linkage.

Additional HMBC measurements (spectrum not shown) revealed besides intra-residue two- and threebond ${ }^{1} \mathrm{H}-{ }^{13} \mathrm{C}$ couplings, also inter-residue three-bond connectivities over the glycosidic linkages, as presented in Table 8, which confirm the sequence analysis results from the NOESY experiments. Also the already proposed anomeric configurations for the various residues fit the ${ }^{1} J_{\mathrm{C}-1, \mathrm{H}-1}$ values found: $\alpha$ Man-B, $171.5 \mathrm{~Hz}$; aMan-C, $\quad 171.5 \mathrm{~Hz}$; aGlc-D, $\quad 170.0 \mathrm{~Hz}$; $\quad$ GGlc-A, $170.0 \mathrm{~Hz}$; $\beta$ GlcA-E, $154.0 \mathrm{~Hz}$.

Combining all analytical data, the structure of EPS 109 is built up from a branched, pentasaccharide repeating unit with the following structure:

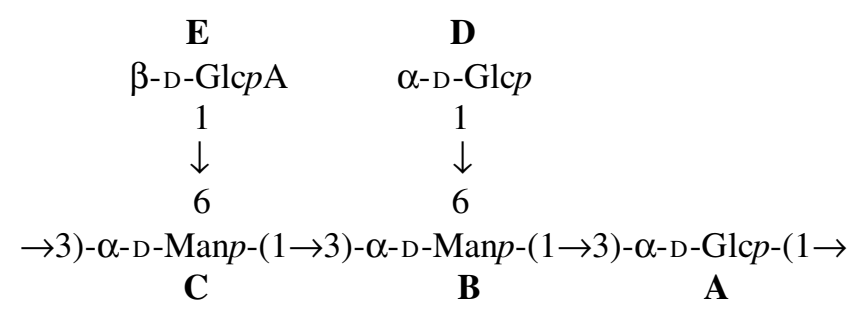

\subsection{Structural analysis of EPS 111 and EPS 126}

The exopolysaccharides EPS 111 and EPS 126, stemming from $P$. freudenreichii 111 and $P$. thoenii 126, respectively, were isolated and purified in the same way as described for EPS 109. As already mentioned in Section 2.1, the monosaccharide, linkage, and 1D ${ }^{1} \mathrm{H}$ NMR analyses suggested for both EPSs a similar structural composition as for EPS 109. Additionally, similar Bio-Gel P-2 profiles of partial acid hydrolysates of EPS 111 and EPS 126 were obtained, yielding also oligosaccharides V5, V6, and V7. Finally, the 2D ${ }^{13} \mathrm{C}-{ }^{1} \mathrm{H}$ HSQC spectra of EPS 111 and EPS 126 were identical to that of EPS 109. Based on these observations, it was concluded that the repeating unit structures of the three exopolysaccharides are identical. 


\subsection{Concluding remarks}

The finding of identical pentasaccharide repeating units for EPS 109, EPS 111, and EPS 126 suggests a phylogenetic relationship between the three propionibacteria strains $P$. freudenreichii 109, P. freudenreichii 111, and $P$. thoenii 126. A similar phenomenon of genetically closely related bacterial strains producing EPSs with identical repeating units has been reported earlier for lactic acid bacteria. ${ }^{25}$ Remarkable is the observed difference in viscosity of the three EPSs, which must be due to differences in the degree of polymerization of the repeating unit. It should be noted that the present EPS structure strongly deviates from that reported for the EPS of $P$. freudenreichii ssp. shermanii JS, being composed of $\rightarrow 3)[\beta-\mathrm{D}-\mathrm{Glc} p-(1 \rightarrow 2)-] \beta-\mathrm{D}-\mathrm{Glc} p-\left(1 \rightarrow\right.$ repeating units. $^{14}$

\section{Experimental}

\subsection{Culture conditions of microorganisms}

The propionibacteria strains $P$. freudenreichii 109, $P$. freudenreichii 111, and $P$. thoenii 126 (University of Warmia and Mazury, Olsztyn, Poland) are maintained anaerobically on APT agar medium (E. Merck, Darmstadt, Germany). For the present investigations, they were subcultured twice in MRS broth (E. Merck) at $30{ }^{\circ} \mathrm{C}$ for $24-48 \mathrm{~h}$.

Culture media were prepared by rehydrating whey powder $(6 \% \mathrm{w} / \mathrm{v}$ solids) obtained from the manufacturer of Edam cheese (SM, Ryki). After adjusting the $\mathrm{pH}$ to 5.0 with $1 \mathrm{M} \mathrm{HCl}$, the whey soln was heated at $121^{\circ} \mathrm{C}$ for $15 \mathrm{~min}$, and the protein precipitate was removed by filtration. To the partially deproteinated whey soln $(840 \mathrm{~mL})$ yeast extract permeate was added to a final concentration of $0.8 \%$, and the $\mathrm{pH}$ was adjusted to 6.3 with $6 \mathrm{M} \mathrm{NH}_{4} \mathrm{OH}$. The medium was sterilized in screw cap bottles at $121{ }^{\circ} \mathrm{C}$ for $15 \mathrm{~min}$. Yeast extract permeate was obtained by dissolving YE powder (E. Merck) in bidistilled water to a final concentration of $50 \mathrm{~g} / \mathrm{L}$, followed by ultrafiltration at $4{ }^{\circ} \mathrm{C}$ using an Amicon centriprep tube (Millipore) with a $10-\mathrm{kDa}$ MW cut off.

The growth of the microorganisms was carried out at $25{ }^{\circ} \mathrm{C}$ for $72 \mathrm{~h}$ with a $1 \%(\mathrm{v} / \mathrm{v})$ inoculum.

\subsection{Isolation of exopolysaccharides}

To the culture medium (750 mL), TFA (E. Merck, Darmstadt, Germany) was added to a final concentration of $4 \%(\mathrm{w} / \mathrm{v})$, and the suspension was stirred for $2 \mathrm{~h}$. Cells and precipitated proteins were removed by centrifugation ( $35 \mathrm{~min}, 22,000 \mathrm{~g}, 4{ }^{\circ} \mathrm{C}$ ). The supernatant was collected and the crude EPS was precipitated with two volumes of cold absolute EtOH (overnight at $4{ }^{\circ} \mathrm{C}$ ). The stringy white mass that formed was spooled on a glass rod, and resuspended in distilled water. An aqueous soln of the precipitated material was extensively dialyzed against bidistilled water for 3 days at $4{ }^{\circ} \mathrm{C}$ with two changes of water per day, and the EPS soln was subsequently lyophilized. The protein content of the EPS was determined with the Pierce Protein Assay Reagent, using bovine serum albumin as a standard. ${ }^{26}$ Since its ${ }^{1} \mathrm{H}$ NMR spectrum did not show extraneous peaks, this lyophilized material of EPS was used for structural analysis without further purification.

\subsection{Partial acid hydrolysis and fractionation of oligosaccharides(-alditols)}

Native polysaccharide $(20 \mathrm{mg})$ was hydrolyzed in portions of $2 \mathrm{mg}$ in $0.5 \mathrm{M}$ TFA $(2 \mathrm{~mL})$ at $100^{\circ} \mathrm{C}$. The progress of the partial acid hydrolysis was followed by analyzing aliquots on TLC (E. Merck Kieselgel 60 F254 sheets; 2:1:1 n-BuOH-HOAc- $\mathrm{H}_{2} \mathrm{O}$; orcinol-sulfuric acid staining), showing an optimal incubation time of $3 \mathrm{~h}$. The soln was lyophilized, and the residue was fractionated by GPC on a Bio-Gel P-2 column $(90 \times 1.5 \mathrm{~cm})$, eluted with $10 \mathrm{mM} \mathrm{NH} \mathrm{NHCO}_{3}$, using refractive index monitoring. Subfractionation of BioGel P-2 fractions was performed by HPAEC-PAD on a Dionex LC system, equipped with a CarboPac PA-1 column $(25 \mathrm{~cm} \times 9 \mathrm{~mm})$. The column was eluted with a gradient of $1 \mathrm{M} \mathrm{NaOAc} / 0.1 \mathrm{M} \mathrm{NaOH}$ (solvent $\mathrm{B}$ ) in $0.1 \mathrm{M} \mathrm{NaOH}$ (solvent $\mathrm{A}$ ) at a flow rate of $4 \mathrm{~mL} / \mathrm{min}$. Gradients were optimized for each fraction. Immediately after collection, the fractions were neutralized with $2 \mathrm{M}$ HOAc, lyophilized, and finally desalted on a Carbograph Extract-Clean column (Alltech). A number of oligosaccharide fractions were reduced with $\mathrm{NaBH}_{4}$ ( $2 \mathrm{~h}$ at room temperature, aqueous soln) prior to subfractionation on the CarboPac PA-1 column using a Dionex LC system.

\subsection{Monosaccharide analysis}

Oligo/polysaccharides were subjected to methanolysis (methanolic $1 \mathrm{M} \mathrm{HCl}, 24 \mathrm{~h}, 85^{\circ} \mathrm{C}$ ). The resulting mixtures of (methyl ester) methyl glycosides were trimethylsilylated (1:1:5 hexamethyldisilazane-trimethylchlorosilane-pyridine; $30 \mathrm{~min}$, room temperature), then quantitatively analyzed by GLC. ${ }^{27}$ In addition, the absolute configurations of the monosaccharides were determined by GLC analysis of the trimethylsilylated (-)-2-butyl glycosides. ${ }^{28}$ For both analyses, the identities of the monosaccharides were confirmed by GLCEIMS. $^{27}$

\subsection{Methylation analysis}

Samples (native EPS, partially hydrolyzed EPS, or oligosaccharides(-alditols)) were permethylated using 
$\mathrm{CH}_{3} \mathrm{I}$ and solid $\mathrm{NaOH}$ in $\mathrm{Me}_{2} \mathrm{SO}$ as described previously. ${ }^{29}$ Part of the permethylated material was directly analyzed as trimethylsilylated methyl glycosides by GLC-EIMS (monosaccharide analysis protocol). The other part was used to prepare partially methylated alditol acetates. After hydrolysis with $2 \mathrm{M}$ TFA $(2 \mathrm{~h}$, $120^{\circ} \mathrm{C}$ ), the partially methylated monosaccharides were reduced with $\mathrm{NaBD}_{4}$ ( $2 \mathrm{~h}$ at room temperature, aqueous soln). Conventional work-up, comprising neutralization (by adding $4 \mathrm{M} \mathrm{HOAc}$ ) and removal of boric acid by coevaporation with $\mathrm{MeOH}$, followed by acetylation with 1:1 pyridine-acetic anhydride $\left(30 \mathrm{~min}, 120^{\circ} \mathrm{C}\right)$, yielded mixtures of partially methylated alditol acetates, which were analyzed by GLC-EIMS. ${ }^{27}$

\subsection{Gas-liquid chromatography and mass spectrometry}

Quantitative GLC analyses were performed on a Chrompack CP9002 gas chromatograph, equipped with an EC-1 column ( $30 \mathrm{~m} \times 0.32 \mathrm{~mm}$, Alltech) using a temperature program of $140-240{ }^{\circ} \mathrm{C}$ at $4{ }^{\circ} \mathrm{C} / \mathrm{min}$ and flameionization detection. The injector temperature was $230^{\circ} \mathrm{C}$ and the detector temperature was $240^{\circ} \mathrm{C}$. GLC-EIMS $(70 \mathrm{eV})$ analyses were carried out on a GC8060/MD800 system (Fisons instruments, Interscience), using an AT-1 column $(30 \mathrm{~m} \times 0.25 \mathrm{~mm}$, Alltech) using the same column temperature program and injector temperature.

MALDI-TOFMS experiments were performed using a Voyager-DE PRO mass spectrometer (Applied Biosystems, Nieuwerkerk aan den IJssel, The Netherlands) equipped with a nitrogen laser $(337 \mathrm{~nm}, 3 \mathrm{~ns}$ pulse width). Positive-ion mode spectra were recorded using the reflector mode and delayed extraction (100 ns). The accelerating voltage was $20 \mathrm{kV}$ with a grid voltage of $75.2 \%$. The mirror voltage ratio was 1.12 , and the acquisition mass range was between 550 and $3000 \mathrm{Da}$. Samples were prepared by mixing on the target $1 \mu \mathrm{L}$ oligosaccharide(-alditol) soln with $2 \mu \mathrm{L}$ aqueous $10 \% 2,5$ dihydroxybenzoic acid as matrix soln.

\subsection{NMR spectroscopy}

Resolution-enhanced 1D/2D 500-MHz ${ }^{1} \mathrm{H}$ NMR spectra and $125-\mathrm{MHz}{ }^{13} \mathrm{C}$ NMR spectra were recorded in $\mathrm{D}_{2} \mathrm{O}$ on a Bruker DRX-500 spectrometer (Bijvoet Center, Department of NMR Spectroscopy, Utrecht University) at a probe temperature of $300 \mathrm{~K}$ for oligosaccharides and polysaccharides. Prior to analysis, samples were exchanged twice in $\mathrm{D}_{2} \mathrm{O}(99.9$ atom $\% \mathrm{D}$, Cambridge Isotope Laboratories, Inc., Andover, MA) with intermediate lyophilization, and then dissolved in $0.6 \mathrm{~mL} \mathrm{D}_{2} \mathrm{O}$. Chemical shifts $(\delta)$ are expressed in ppm by reference to internal acetone $\left(\delta 2.225\right.$ for ${ }^{1} \mathrm{H}$ and 31.07 for ${ }^{13} \mathrm{C}$ ). Suppression of the HOD signal was achieved by applying a WEFT pulse sequence for 1D experiments and by a pre-saturation of $1 \mathrm{~s}$ during the relaxation delay in 2D experiments. 2D TOCSY spectra were recorded using an MLEV-17 mixing sequence with spin-lock times of 40-200 ms. 2D NOESY experiments were performed with a mixing time of $50 \mathrm{~ms}$. 2D ROESY spectra were recorded using standard Bruker XWINNMR software with mixing times of 200 $250 \mathrm{~ms}$. The carrier frequency was set at the downfield edge of the spectrum to minimize TOCSY transfer during spin-locking. Natural abundance $2 \mathrm{D}^{13} \mathrm{C}-{ }^{1} \mathrm{H}$ HSQC and $\mathrm{HMBC}$ experiments were recorded without decoupling during acquisition of the ${ }^{1} \mathrm{H}$ FID. Resolution enhancement of the spectra was performed by a Lorentzian-to-Gaussian transformation for 1D spectra or by multiplication with a squared-bell function phase shifted by $\pi /(2.3)$ for $2 \mathrm{D}$ spectra, and when necessary, a fifth order polynomial baseline correction was performed. All NMR data were processed using in-house developed software (J.A. van Kuik, Bijvoet Center, Department of Bio-Organic Chemistry, Utrecht University).

\section{Acknowledgment}

J.M.D. has been financially supported by a Marie Curie Host Fellowship-HPMT-CT-2001-00389.

\section{References}

1. Sutherland, I. W. Trends Biotechnol. 1998, 16, 41-46.

2. Duboc, P.; Mollet, B. Int. Diary J. 2001, 11, 759-768.

3. De Vuyst, L.; Degeest, B. FEMS Microbiol. Rev. 1999, 23, 153-177.

4. Welman, A. D.; Maddox, I. S. Trends Biotechnol. 2003, 21, 269-274.

5. Cerning, J. Lait 1995, 75, 463-472.

6. Cummins, C. S.; Johnson, J. L. In The Prokaryotes; Balows, A., Trüper, H. G., Dworkin, M., Harder, W., Schleifer, K. H., Eds.; Springer: New York, 1992; Vol. 1, pp 834-849.

7. Vorob'eva, L. I. Propionibacteria; Kluwer Academic Publishers: Dordrecht, The Netherlands, 1999.

8. Mantere-Alhonen, S. Lait 1995, 75, 447-452.

9. Laws, A.; Gu, Y.; Marshall, V. Biotechnol. Adv. 2001, 19, 597-625.

10. Ruas-Madiedo, P.; de los Reyes-Gavilan, C. G. J. Dairy Sci. 2005, 88, 843-856.

11. Crow, V. L. Appl. Environ. Microbiol. 1988, 54, 18921895.

12. Racine, M.; Dumont, J.; Champagne, C. P.; Morin, A. J. Appl. Bacteriol. 1991, 71, 233-238.

13. Gorret, N.; Renard, C. M. G. C.; Famelart, M. H.; Maubois, J. L.; Doublier, J. L. Carbohydr. Polym. 2003, $51,149-158$.

14. Nordmark, E.-L.; Yang, Z.; Huttunen, E.; Widmalm, G. Biomacromolecules 2005, 6, 521-523.

15. Ruas-Madiedo, P.; Hugenholtz, J.; Zoon, P. Int. Diary J. 2002, 12, 163-171. 
16. Perez Chaia, A.; Zarate, G.; Oliver, G. Lait 1999, 78, 175185.

17. Torino, M. I.; Mozzi, F.; Font de Valdez, G. Milchwissenschaft 2000, 55, 314-316.

18. Bock, K.; Thøgersen, H. Annu. Rep. NMR Spectrosc. 1982, 13, 1-57.

19. Bock, K.; Pedersen, C. Adv. Carbohydr. Chem. Biochem. 1983, 41, 27-66.

20. Roger, O.; Kervarec, N.; Ratiskol, J.; Colliec-Jouault, S.; Chevolot, L. Carbohydr. Res. 2004, 339, 2371-2380.

21. Hawkes, G. E.; Lewis, D. J. Chem. Soc., Perkin Trans. 2 1984, 2073-2078.

22. Angyal, S. J.; LeFur, R. Carbohydr. Res. 1980, 84, 201209.

23. Robijn, G. W.; Thomas, J. R.; Haas, H.; van den Berg, D. J. C.; Kamerling, J. P.; Vliegenthart, J. F. G. Carbohydr. Res. 1995, 276, 137-154.
24. Robijn, G. W.; Gutiérrez Gallego, R.; van den Berg, D. J. C.; Haas, H.; Kamerling, J. P.; Vliegenthart, J. F. G. Carbohydr. Res. 1996, 288, 203-218.

25. Marshall, V. M.; Laws, A. P.; Gu, Y.; Levander, F.; Rådström, P.; De Vuyst, L.; Degeest, B.; Vaningelgem, F.; Dunn, H.; Elvin, M. Lett. Appl. Microbiol. 2001, 32, 433437.

26. Bradford, M. M. Anal. Biochem. 1976, 72, 248254.

27. Kamerling, J. P.; Vliegenthart, J. F. G. Carbohydrates. In Mass spectrometry; Lawson, A. M., Ed.; Clinical Biochemistry-Principles, Methods, Applications; Walter de Gruyter: Berlin, 1989; Vol. 1, pp 175-263.

28. Gerwig, G. J.; Kamerling, J. P.; Vliegenthart, J. F. G. Carbohydr. Res. 1979, 77, 1-7.

29. Ciucanu, I.; Kerek, F. Carbohydr. Res. 1984, 131, 209217. 